\title{
Tailoring in fungi for next generation cellulase production with special reference to CRISPR/CAS system
}

\author{
Subhadeep Mondal ${ }^{1}$ Suman Kumar Halder ${ }^{2} \cdot$ Keshab Chandra Mondal $^{2}$
}

Received: 20 May 2021 / Revised: 14 July 2021 / Accepted: 15 July 2021 / Published online: 29 July 2021

(c) Jiangnan University 2021

\begin{abstract}
Cellulose is the utmost plenteous source of biopolymer in our earth, and fungi are the most efficient and ubiquitous organism in degrading the cellulosic biomass by synthesizing cellulases. Tailoring through genetic manipulation has played a substantial role in constructing novel fungal strains towards improved cellulase production of desired traits. However, the traditional methods of genetic manipulation of fungi are time-consuming and tedious. With the availability of the full-genome sequences of several industrially relevant filamentous fungi, CRISPR-CAS (clustered regularly interspaced short palindromic repeats/CRISPR-associated protein) technology has come into the focus for the proficient development of manipulated strains of filamentous fungi. This review summarizes the mode of action of cellulases, transcription level regulation for cellulase expression, various traditional strategies of genetic manipulation with CRISPR-CAS technology to develop modified fungal strains for a preferred level of cellulase production, and the futuristic trend in this arena of research.
\end{abstract}

Keywords Cellulose $\cdot$ Cellulase $\cdot$ Fungi $\cdot$ Genetic manipulation $\cdot$ CRISPR $\cdot$ CAS

\section{Introduction}

Lignocellulosic biomass covers the earth's largest reservoir of inexhaustible resources, representing about 1.3 billion tons per year [1,2]. Cellulose comprises a significant fraction of lignocellulosic biomass, sharing up to $50 \%$, and globally it is the most plentiful polysaccharide. Cellulose is a linear polymer consisting of $\beta$-1,4-linked D-glucose residues [3]. Hydrogen bonds tightly hold these glucose chains to form insoluble fibrous materials. Structurally, a two-phase model involving crystalline and amorphous phases intermittent with a chain of semi-crystalline structures makes it challenging to utilize active carbohydrate degrading enzymes [4]. As a polysaccharide, cellulose served as a significant milestone of bioenergy production (methane, ethanol, and biofuels), making it a hot topic of renewable bioenergy

Suman Kumar Halder

sumanmic85@gmail.com

$\triangle$ Keshab Chandra Mondal mondalkc@gmail.com

1 Center for Life Sciences, Vidyasagar University, Midnapore 721102, West Bengal, India

2 Department of Microbiology, Vidyasagar University, Midnapore 721102, West Bengal, India research [5]. The most efficient, eco-friendly, and sustainable biomass hydrolysis (cellulosic fraction) method is the enzymatic saccharification by cellulase. More than two centuries ago, Anselme Payne was the first to discover and isolate these incredible enzymes from plants [6].

Enzymatic hydrolysis of cellulose required collaborative action of three enzymes: endoglucanase or CMCase (EG) (EC 3.2.1.4), which cleaves internal $\beta$-1,4-glucosidic bonds randomly; exoglucanase or cellobiohydrolase (CBH) (EC.3.2.1.91), which cleaves off cellobiose units from the ends and $\beta$-glucosidase (BGL) (EC.3.2.1.21), which transforms cellobiose and cellodextrins into glucose [7, 8]. For cellulase production, fungi are preferable to bacteria because bacterial cellulase usually lacks one of the three cellulolytic activities (exoglucanase activity), downstream processing of fungal cellulase is much easier than bacterial cellulases, and the activity of fungal cellulase is far greater than that of the bacterial cellulase [6]. Fungi is regarded as one of the earliest eukaryotic life appearing on the earth, confirmed by the fossils dating ( $0.45-0.46$ billion years ago) [138]. The ecological significance of fungi is due to their potentiality as dominant decomposers in the ecosystem. Filamentous fungi are major cellulase producers, including Trichoderma reesei, Aspergillus niger, Neurospora crassa, and Penicillium 
oxalicum, gain special attention and have been rigorously studied [9].

Due to a diverse range of industrial applications like pulp and paper, bakery, textile, food processing, agricultural, biotechnology, etc., cellulases have a massive demand among the commercialized industrial enzymes [10]. They constitute $\sim 3 / 4$ of the need for total enzymes required in biorefineries, pulp and paper, textile, and food/feed industries [11]. According to Markets and Markets report, 2020 (https:// www.marketsandmarkets.com) the global enzyme market is projected to grow from 10 billion US dollar in 2019 to 14.7 billion US dollar in 2025, and cellulase is a frontrunner candidate of the global enzyme market. Cellulases' market value emerging at $5.5 \%$ expected compound annual growth rate during 2018-2025 and will reach 2300 million US dollar by 2025 [12]. However, the high expenditure of cellulase production is one of the bottlenecks for the industrialization of lignocellulosic bioconversion. Researches on cellulase production using wild-type strains of fungi have been done extensively. Still, the main drawbacks of the wild-type strains are the unavailability of hyper-producing efficient strain, incapability of large-scale production, and incompetence to tolerate industrial operations' extreme conditions [147]. The cellulases from Aspergillus sp. usually have high BGL levels and lower EG activity; on the other side, Trichoderma has high EG and CBH activity but lowers BGL level, so there is some extent of limitation in efficient cellulose hydrolysis [13].

Genetic modification of fungal strains through traditional methods or CRISPR/CAS system enables the synthesis of cellulase with enhanced catalytic properties that can manage the demand of industrial sectors [14]. However, simultaneous operation at multiple target sites is the major bottleneck of traditional genome editing tools. The CRISPR-CASmediated double-stranded breaks are repaired by the process of nonhomologous end-joining, differ from the homologous recombination where long sequence homology is obligatory. The cutting-edge genome-editing approaches such as split marker technique, transcription activator-like effector nucleases (TALENS), and zinc finger nucleases (ZFNs) also have some complications like time-taking multiple rounds of marker selection and difficulties in the preparation of specific DNA binding proteins along with inadequacy in simultaneous editing of multiple targets. The CRISPR-CAS system gets over from such difficulties. Besides, multiplexed CRISPR strategy (a modified version of the CRISPR-CAS system) allows synchronized activation or repression of genes during the editing of metabolic pathways $[15,16]$.

Different attributes of enzyme viz. enantioselectivity, stereospecificity, substrate specificity, enzyme activity, enzyme stability, and tolerance have been ameliorated through genetic manipulations [17]. For the production food grade cellulases, manufacturers should be conscious about the safety issues. By deploying this approach, it is possible to produce cellulase in a non-pathogenic strain by introducing the cellulase gene of the pathogenic one, which is suitable for food safety. In contemporary times, innovative methods and tools at the molecular level have continuously flourished, which intensified the proficiency of genetic manipulation of filamentous fungi for the hyper-production of cellulase. In this deliberation, we shall discuss a brief account of the biochemical, genetic, and molecular nature of cellulase and different genetic manipulation approaches applicable in fungi with special emphasis on CRISPER/CAS technology for improved cellulase production.

\section{Functional properties of cellulases}

Cellulose is a hydrophilic, water-insoluble polymer comprising repetitive units of D-glucose linked together by $\beta-1,4-$ glycosidic bonds. Cellulases belong to the glycoside hydrolases (GHs) class, which degrade cellulose into cellodextrin, cellobiose, and glucose. In general, they comprise a catalytic domain (CD) that breaks down the glycoside bond and carbohydrate-binding module (CBM) that sets the targets of $\mathrm{CD}$ to their polysaccharide substrate. Three different cellulolytic enzymes namely CBH, EG and BGL acts synergistically and hydrolyzes cellulose fibre (Table 1). The EG acts randomly on the cellulose fibre in the internal site exposes reducing and non-reducing ends. The $\mathrm{CBH}$ acts on these reducing and non-reducing ends to produce cello-oligosaccharides and cellobiose moieties. Finally, the BGL breaks cellobiose and releases glucose (Singhania et al. 149).

Hydrolysis of the cellulose crystalline structure is assisted by lytic polysaccharide monooxygenase (LPMOs), non-hydrolytic proteins, triggering nicks on cellulose fibers to quicken the endoglucanase action. The LPMOs are oxidative enzymes, require an external electron donor (in this case lignin) and molecular oxygen or hydrogen peroxide for their catalytic activity, and elevate the hydrolytic potentiality of glycoside hydrolases (GHs) in the course of the depolymerization of recalcitrant polysaccharides, such as cellulosic biomass. [18]. Commercial cellulase preparations currently include LPMOs as their presence reasonably minimizes enzyme loading [19]. Expansins is a kind of proteins does not have any hydrolytic activity, instead, it is hypothesized to act as a zipper to untie the cross-links between the cellulose microfibrils by relaxing the firmly adhered chains, led to increasing cellulose exposure to cellulases [20]. Expansin-like proteins have been recognized in both bacteria and fungi. Baker et al. [21] reported a mixture of expansin and cellulases from $T$. reesei, resulting in a $13 \%$ enrichment in cellulose conversion rate in terms of sugar released from the pretreated yellow poplar sawdust in comparison to cellulase only. Combining recombinant 
Table 1 Cellulolytic enzymes, their catalytic pattern, and the cellulase genes of different fungal species Modified version reported by [20, 23, 96]

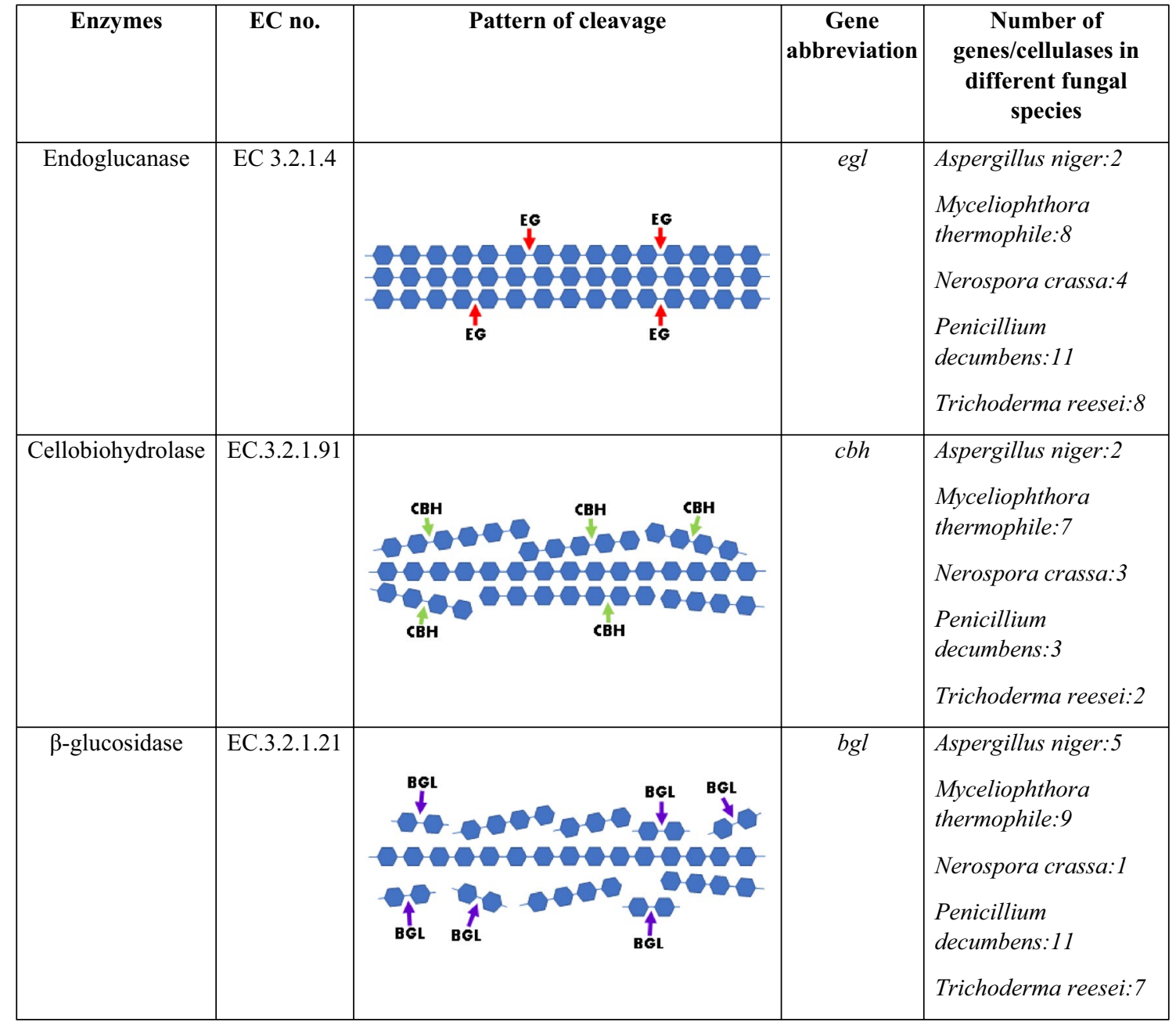

EXLX1 protein (a member of the expansin superfamily) and commercial $T$. reesei cellulases led to enhancement of cellulolytic activity [20]. Another protein known as swollenin (expansins like proteins, belonging to glycosyl hydrolase family 45) isolated from $T$. reesei, participates in the deconstruction of the plant cell wall by breaking the hydrogen bond between the microcrystalline cellulose, facilitating further cellulase hydrolysis. Besides, swollenin exhibits glycoside hydrolase activity [20, 22]. Therefore, all these enzymes or proteins act together in a perfect synergism to cleave such a recalcitrant cellulose crystalline structure.

\section{Molecular mechanisms behind the cellulase expression}

Plant cell wall polysaccharides' efficient breakdown requires various cellulases to be secreted in massive amounts and a complex regulatory system to control cellulase-related genes. These genes are regulated by several transcription factors (TFs) (Table 2), which are the potential targets for the genetic manipulation of cellulase production. Moreover, efficient genetic engineering of a specific preferred gene in an organism requires detailed knowledge about its genome's genetic architecture and the regulatory mechanism behind that particular gene of interest. A maximum number of TFs participated in such regulatory mechanisms (Fig. 1), particularly from the Zn2Cys6 zinc binuclear cluster family, specifically in fungi [16].

\section{Genetic manipulation for intensified cellulase production}

The ability of dominant fungal genera of cellulases producers like Trichoderma, Aspergillus, Neurospora, Myceliopthora, and Penicillium spp. for cellulosic biomass degradation has been practiced formerly. The development of 
Table 2 Transcription factors involved in cellulase expression

\begin{tabular}{|c|c|c|}
\hline Transcription factors & Function & References \\
\hline Tmk1, Tmk2, and Tmk3 & $\begin{array}{l}\text { In } T \text {. reesei, it causes phosphorylation and activation of TFs liable for cellulase (cbh1, } \\
\text { cbh2, egl1, egl2, and bg11) production. Removal of } t m k 3 \text { down regulated the tran- } \\
\text { scription level expression of cbh1, cbh2, egl1, egl2, and bgl1 }\end{array}$ & [97] \\
\hline $\mathrm{X} \operatorname{lnR} / \mathrm{Xyr} 1$ & $\begin{array}{l}\text { XlnR (xylanase regulator), primarily in Aspergillus sp., and Xyr1 (xylanase regulator } \\
\text { 1), primarily in } T \text {. reesei are the prime transcriptional activators of the genes encod- } \\
\text { ing cellulase (cbhl, cbh2, egll, and } b g l l \text { ) enzymes }\end{array}$ & [98] \\
\hline RXE1 & $\begin{array}{l}\text { It (RXE1 orthologs in Aspergillus chrysogenum, Beauveria bassiana, and Fusarium } \\
\text { oxysporum are designated BRLA) regulate cellulase gene expression, exhibits intense } \\
\text { binding activity to the } x y r 1 \text { promoter }\end{array}$ & [99] \\
\hline Rce1 & $\begin{array}{l}\text { It acts as a transcriptional repressor for cellulase gene expression by binding at the } \\
c b h 1 \text { promoter region, antagonized Xyr } 1 \text { from binding to the } c b h l \text { promoter }\end{array}$ & {$[100]$} \\
\hline $\mathrm{BglR}$ & $\begin{array}{l}\text { It positively regulates the expression of genes encoding BGL in } T \text {. reesei. Its activation } \\
\text { causes repression of the } \mathrm{CBH} \text { and } \mathrm{EG} \text { genes }\end{array}$ & [101] \\
\hline ClbR & $\begin{array}{l}\text { In A. aculeatus it regulates cellulase-encoding genes induced by cellulose and cel- } \\
\text { lobiose }\end{array}$ & {$[102]$} \\
\hline Ace3 & $\begin{array}{l}\text { In } T \text {. reese } i \text {, its overexpression led to increase cellulase gene expression, while its } \\
\text { removal causes a remarkable reduction in cellulase activity }\end{array}$ & [103] \\
\hline CreA/Cre1 & $\begin{array}{l}\text { They regulates CCR (carbon catabolite repression) where, in the existence of simple } \\
\text { sugars such as glucose, fructose, mannose or xylose, it suppresses the transcription } \\
\text { of genes encoding enzymes involved in the metabolism of more complex polysac- } \\
\text { charides }\end{array}$ & [104] \\
\hline Crz1 & $\begin{array}{l}\text { Through the conduction of } \mathrm{Ca}^{2+} / \mathrm{Mn}^{2+} \text { mediated signalling, it affects the promoter } \\
\text { region of xyr1 and cbh1, and induced cellulase production }\end{array}$ & {$[105],[135]$} \\
\hline Ctf1 & $\begin{array}{l}\text { In } T \text {. reesei, it downregulate RCE1 gene, thus it upregulate genes of the transcription } \\
\text { factors XYR1 and ACE3, resulting in the activation of cellulolytic genes }\end{array}$ & [106] \\
\hline $\mathrm{Clr}-1 / \mathrm{Clr}-2 / \mathrm{Clr}-3$ & $\begin{array}{l}\text { Activation of the Clr- } 1 \text { requires the presence of an inducer such as cellobiose, prompts } \\
\text { expressions of bgl, but Clr- } 2 \text { does not require any inducer for its activation. Abolition } \\
\text { of them in } N \text {. crassa may prevent cellulose utilization as a carbon source }\end{array}$ & [107] \\
\hline Clr-3 & $\begin{array}{l}\text { Clr- } 3 \text { prevent the activity of } \mathrm{Clr}-1 \text {, removal of it led to the Clr- } 1 \text { mediated gene expres- } \\
\text { sion in the absence of inducer }\end{array}$ & [108] \\
\hline HAP complexes & $\begin{array}{l}\text { HAP complexes are recognized in Aspergillus spp. }(\mathrm{HapB} / \mathrm{C} / \mathrm{E}), \text { T. reesei }(\mathrm{Hap} 2 / 3 / 5) \text {, } \\
\text { and } N \text {. crassa }(\mathrm{Hap} 2 / 3 / 5) \text {. They allow moderate expression of cellulase and xylanase } \\
\text { genes in } T \text {. reesei }(\text { cbh2 and xyn } 2)\end{array}$ & [109] \\
\hline Lae1 and VELVET complex & $\begin{array}{l}\text { In } T \text {. reesei (LaeA orthologue in A. nidulans), it act as a methyltransferase induces } \\
\text { cellulase expression and forming the VELVET complex, which in turn regulates the } \\
\text { transcription of major cellulase genes }\end{array}$ & [110] \\
\hline $\mathrm{PacC} / \mathrm{Pac} 1$ & $\begin{array}{l}\text { In } A \text {. nidulans and } T \text {. reesei, it respond to } \mathrm{pH} \text { variance in the external environment, } \\
\text { stimulate or prevent cellulase production. At neutral } \mathrm{pH} \text {, the abolition of the pac1 } \\
\text { gene increases Xyr1 activity }\end{array}$ & {$[5,55]$} \\
\hline PoxMBF1 & $\begin{array}{l}\text { In Penicillium oxalicum, it binds directly to the promoter regions of principal cellulase } \\
\text { and xylanase genes to induce cellulase production }\end{array}$ & [111] \\
\hline PoxFlbC & $\begin{array}{l}\text { In Penicillium oxalicum (FlbC orthologue in Aspergillus), it upregulates most of the } \\
\text { cellulase genes }\end{array}$ & [112] \\
\hline PoxAtf1 & $\begin{array}{l}\text { In filamentous fungi, it controls the expression of cellulase and xylanase genes during } \\
\text { the solid-state fermentation }\end{array}$ & [113] \\
\hline Blr1, Blr2, and Env1 & $\begin{array}{l}\text { Photoreceptor proteins (Blr1, Blr2, and Env1) in both light and dark regulate the cellu- } \\
\text { lase gene from T. reesei. The photoreceptor regulative mechanism of carbon metabo- } \\
\text { lism in T. reesei is dependent on Blr1 and Blr2 controlled by the Env1 photoreceptor }\end{array}$ & [114] \\
\hline Seb1 & $\begin{array}{l}\text { In Talaromyces pinophilus EMU, Seb1 transcription factor binds to the stress response } \\
\text { element (STRE) and CRISPR-Cas } 9 \text { mediated degradation of seb1 gene led to the } \\
20-40 \% \text { increment in FPase activity }\end{array}$ & [123] \\
\hline TrAZF1 & $\begin{array}{l}\text { In } T \text {. reesei and } A \text {. nidulans positively regulates the activity of BGL and CBH by inter- } \\
\text { acting with the cel7a, cel } 45 a \text {, and sow promoter region }\end{array}$ & [115] \\
\hline PoSet1/PoSet 2 & $\begin{array}{l}\text { In Penicillium oxalicum, PoSet } 1 \text { and PoSet } 2 \text { are responsible for methylation of histone } \\
\text { (H3) lysine } 4 \text { and lysine } 36 \text {, respectively. They are involved in the upregulation } \\
\text { (PoSet } 1 \text { ) or down regulation (PoSet } 2 \text { ) of cellulase production }\end{array}$ & [116] \\
\hline
\end{tabular}


Table 2 (continued)

\begin{tabular}{lll}
\hline Transcription factors & Function & References \\
\hline MAT1-2-1 & $\begin{array}{l}\text { It is a mating-type locus protein of T. reesei modulates cellulase gene expression in } \\
\text { daylight by interacting with the Xyr1 and binds to the } c b h 1 \text { promoter }\end{array}$ & [117]
\end{tabular}

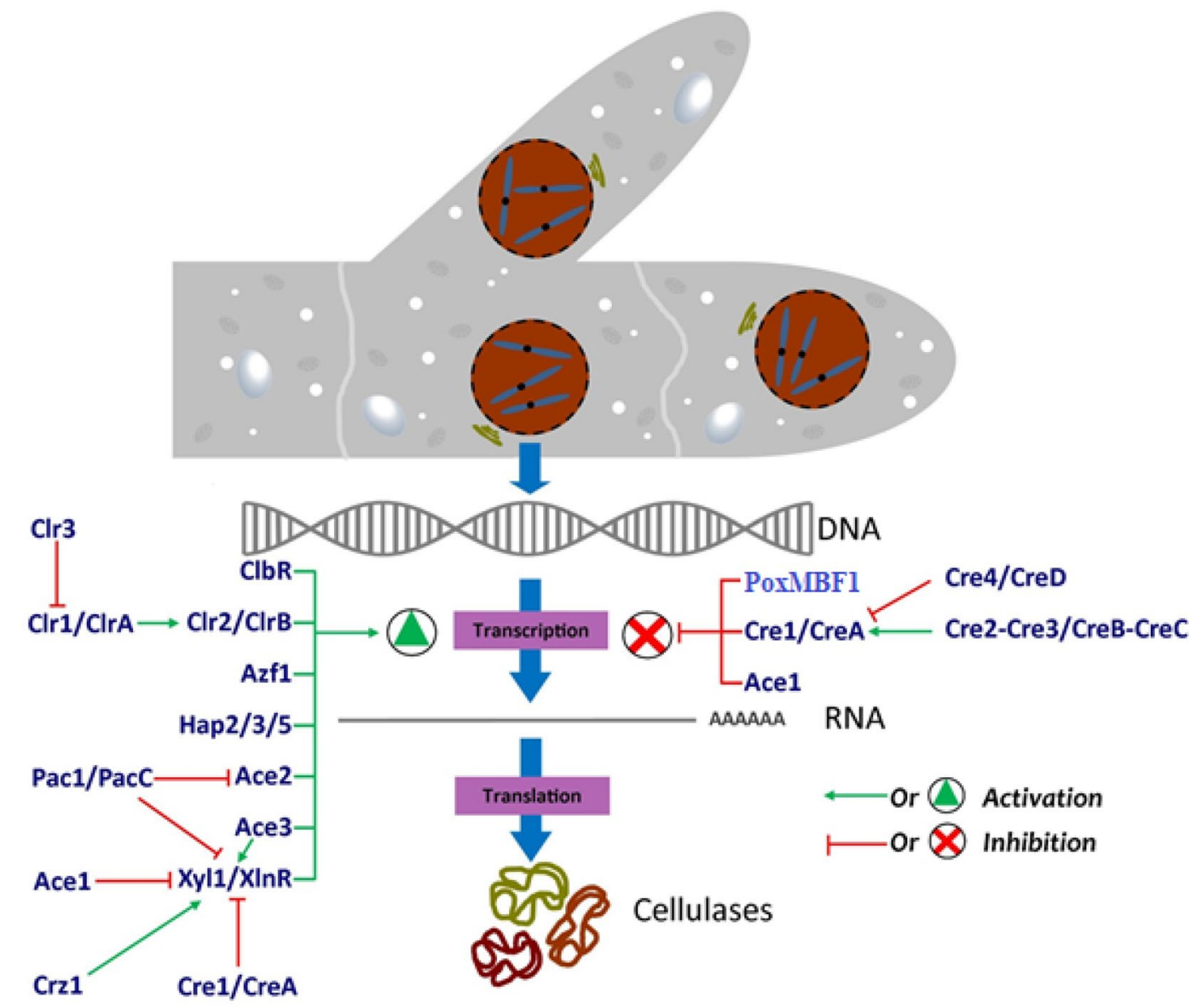

Fig. 1 Schematic overview of the transcriptional regulatory network of genes encoding cellulolytic enzymes in fungi

a fungal strain with an extraordinary saccharification efficiency and enzymatic activities for cellulose hydrolysis has remained a bottleneck. It is now renowned that a consortium of enzymes is obligatory for proficient degradation of cellulose; therefore, several genetic modifications of these fungi are needed for the cost-effective production of highly efficient cellulases, which has improved features such as higher yield, more excellent specific activity, superior stability $(\mathrm{pH}$ and temperature), and less susceptible to substrate-level inhibition $[14,23]$. Several well-established genetic manipulation strategies (Fig. 2) in fungi for improved cellulase production are elaborated. A comparative account of different documented genetic manipulation strategies for betterment of fungal cellulase production was presented in Table 3.

Transcriptional regulators such as inducers and inhibitors profoundly affect gene expression. By adding or deleting such regulators, the expression level of the subjected gene can be substantially improved. TFs modification is a proficient strategy to increase enzyme production in fungi. The Xyr1 positively regulates cellulase induction since its abolition removes all possible inducers based on cellulase induction, while overexpression boosts cellulase induction [23]. Twenty six percent overexpression xyrl gene of Trichoderma harzianum prompts 36, 37 and $66 \%$ increment in the $\beta$-glucosidase, xylanase and FPase activity, respectively. The increment in enzymatic activities facilitates a $25 \%$ rise in the rate of sugarcane bagasse saccharification in the initial $24 \mathrm{~h} \mathrm{[24].} \mathrm{Besides,} \mathrm{the} \mathrm{constitutive} \mathrm{expression} \mathrm{of} \mathrm{the}$ xyrl (V821F) mutant led to a decrease in glucose repression [25] in T. reesei; therefore, enhanced cellulase and xylanase synthesis achieved on sugarcane bagasse [26]. Cre1 inhibits both the basal and inducible expressions as a principal 


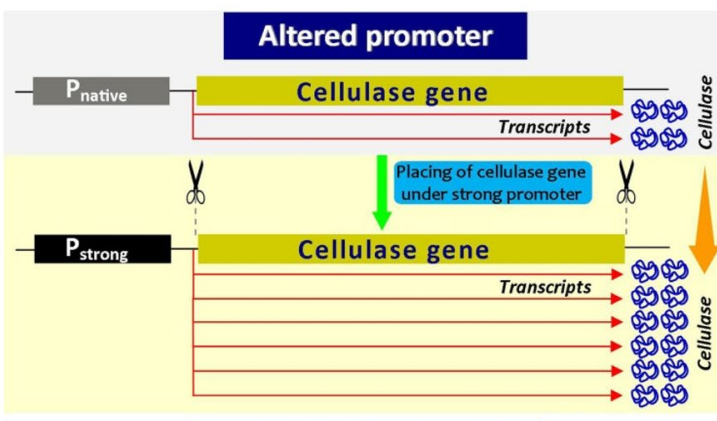

Regulator manipulation

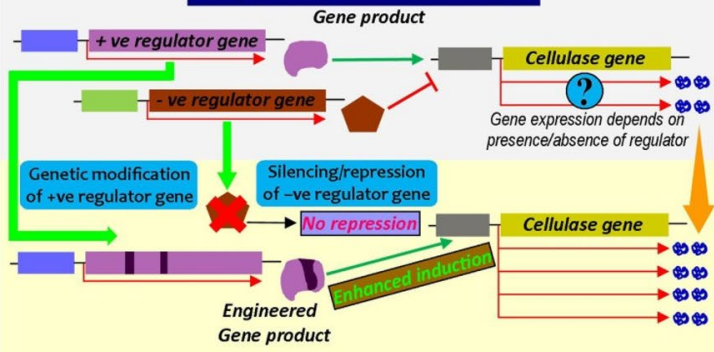

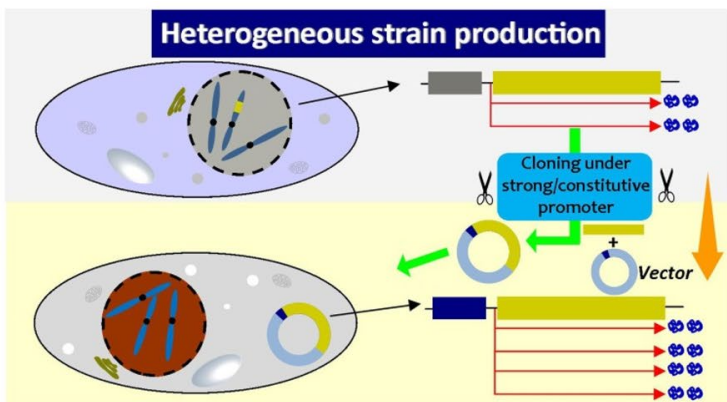

Metabolic engineering

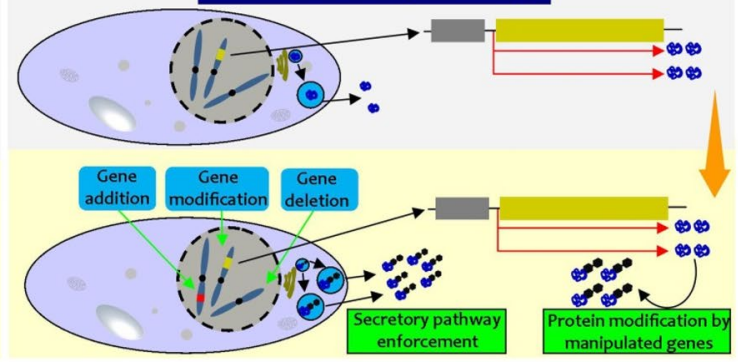

Fig. 2 Overview of different approaches of genetic and metabolic engineering for enhancement of cellulose production by fungi

negative regulator, thus maintaining the carbon catabolite repression (CCR) and avert xyrl gene expression. In T. ree$s e i$, the elimination of Cre1, which is responsible for suppressing carbon metabolism, is involved in the elevation of overall cellulase synthesis [27]. Zhang et al. [28] build a hybrid cellulase regulator involving the DNA-binding domain of the glucose-repressor Cre1 merged with Xyr1 effector binding domains, and overexpression of it led to the 30 -fold increment in the constitutive expression of cellulase and hemicellulase when glucose was utilized as a primary carbon source in $T$. reesei.

$R N A$ interference ( $R N A i$ ) technology has been positively implemented in regulating the $\mathrm{crel}$ gene expression in $T$. koningii led to the disturbing transcriptional level expression of crel at varying degrees, resulting in increased activity of total cellulase level [29]. Besides, Wang et al. [30] also concomitantly executed RNA interference of Ace1 and overexpression of the positive regulator Xyr1 leading to many fold increments in extracellular protein secretion and filter paper activity in T. reesei Rut-C30 mutant. Moreover, artificial TFs have also been utilized for augmented cellulase production in $T$. reesei. Novel artificial TFs are synthesized by fusing several cellulases producing DNA-binding domains from positive and negative regulatory TFs in $T$. reesei with an activation domain of VP16 protein of herpes simplex virus. These TFs have incredible regulatory effects on cellulase production, improving the cellulase activity by $50 \%-80 \%$ than the parental strain in various inducing conditions [31]. Besides, novel minimal transcriptional activators having the DBD-Ace2 and the VP16 effecting domain outstandingly enhanced cellulase production, i.e., over 25 -fold increment in FPase activity compared to the parental strain $T$. reesei Rut-C30, when utilizing glucose as the sole source of carbon [32]. Vib-1 has reported asserting regulation of cellulase synthesis in $N$. crassa [33] and overexpression of its homologous gene Trvib-1 in T. reesei, resulting in improved cellulase production [34].

Promoters play a pitotal role in the context of gene expression. Incorporating a strong promoter upstream of the gene of interest allows the desired level of gene expression. For manufacturing highly competent fungal strains of cellulase production, native promoters play a crucial role since cellulase expression is operated at the transcriptional level. Cellobiohydrolase 1 (CBH1) is the foremost secretory protein in $T$. reese $i$; therefore, the $c b h 1$ promoter has been widely used to induce hyperproduction of target proteins in T. reesei. It is known that the $\beta$-glucosidase (BGL) activity is deficient in T. reesei. It has been reported that in T. reesei, the application of such strong inducible promoters of $c b h 1$ and $c b h 2$ led to overexpression of BGL and other cellulases, which significantly expand the overall hydrolase activities [35]. Rahman et al. [140] reported that the activity of BGL has also been increased to many folds when the bgll gene express from the egl 3 and $x y n l$ promoters. The reorganization of cis-elements of Xyr1 in the $c b h 1$ promoter leads to a sevenfold increment in the $c b h 1$ promoter strength [36].

Similarly, in the manipulated xyn 3 promoter, the cis-acting area is exchanged to the cis-acting site of the xyn1 promoter, improving the expression of A. aculeatus bgll; therefore, amplified the overall cellulase hydrolysis efficiency 


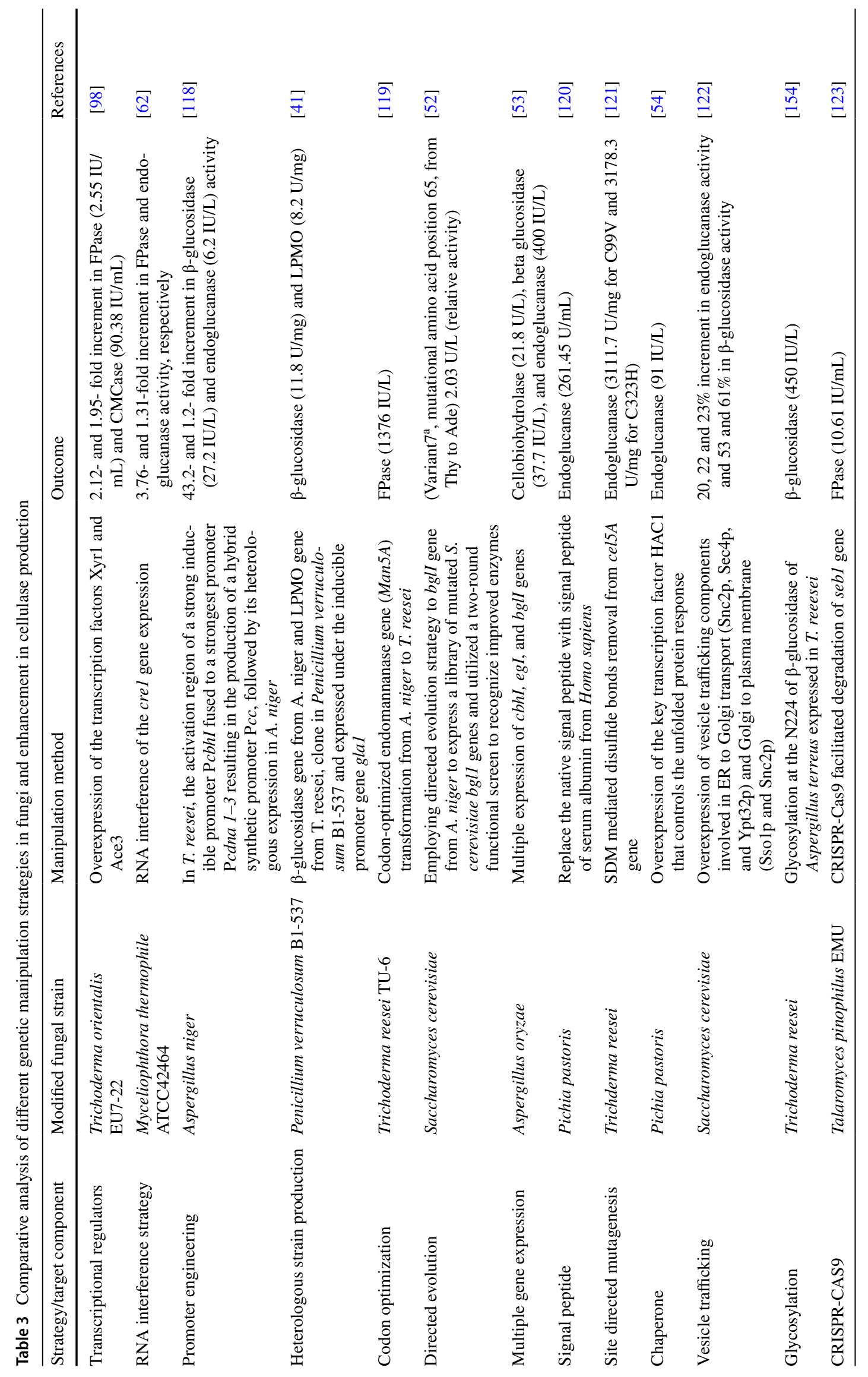


[37]. The binding sites of transcription regulators are also manipulated to raise the production. Zou et al. [149] incorporated ACE2 and HAP3/HAP2/HAP5 by replacing the cre1 binding site for the transcriptional activators inside the $c b h 1$ promoter, which led to a sevenfold improvement in cellulase expression. According to the report, the $c b h 1$ promoter is regulated by the carbon catabolite repressor (crel), particularly when glucose is available. Promoter competence could be enhanced under the umbrella of CCR if the crel binding sites can be substituted by the sequence where transcriptional activators bind. Wang et al. [38] established a promoter pool for the transformation of alkaline cellulase genes in $T$. reesei involved in multienzymes biosynthesis, which act together to alter the fabric surface as bio-stoning agent.

Heterologous strain production involves gene expression (or parts of it) of interest in a host organism lacking this gene or gene fragment naturally. A heterologous gene construct has been prepared by fusing A. cellulolyticus endoglucanase catalytic core with the catalytic core and linker of $T$. reesei cbhl and expressed in $T$. reesei. This recombinant protein product becomes functionally more efficient in cellulose hydrolysis of up to $20 \%$ within $6 \mathrm{~h}$ [150]. The Cel7A exoglucanase of $T$. reese $i$ has been incorporated and expressed in A. niger. The recombinant strain is grown on spent hydrolysates (stillage) from sugarcane bagasse and can ingest Picea hydrolysate with enhanced endoglucanases activity than $T$. reesei. The cellulase gene cloned in A. niger was under a constitutive promoter to relieve the glucose repression in $T$. reese $i$ strains [39]. For cellulase production in $T$. reesei, utilization of the repressor sugars present in molasses (sucrose, fructose, glucose), Ellilä et al. [26] has been developed a recombinant strain (VTT-BR-C0019) by expressing an improved Xyr1 TF under the constitutive pyruvate decarboxylase $(p d c 1)$ promoter. The manipulated strain exhibits increased cellulase production with the expression of an EG under the presence of the repression sugar glucose. In achieving higher level expression of the BGL, they cloned and overexpressed the Cel3A $\beta$-glucosidase from the moderate thermophilic fungus Talaromyces emersonii in the VTT-BR-C0019 to construct VTT-BR-C0020 strain. Furthermore, they cloned the invertase-expressing gene (VTT-BR-C0022) from A. niger to utilize sucrose in molasses. The final manipulated strain (VTT-BR-C0022) has shown better hydrolytic productivity utilizing lignocellulosic biomass with a concurrent drop in processing cost. A thermostable $\beta$-glucosidase from Thermoascus aurantiacus has been cloned and expressed in Pichia pastoris. The resultant recombinant yeast strain can be utilized cellobiose as a carbon source [40]. Simultaneous expression of $\mathrm{bgll}$ encoding BGL from A. niger (AnBGL) and egl4 encoding LPMO (previously endoglucanase IV) from $T$. reesei (TrLPMO) have been cloned in Penicillium verruculosum utilizing the inducible glal promoter, led to the far better hydrolysis of lignocellulosic biomass in contrast with the wild type strain [41]. The $g p d A$ promoter (isolated from $A$. nidulans) mediated overexpression of $c l r B$ in $P$. oxalicum, resulting in higher cellulase levels [42]. In the yeast strain Pichia pastoris X33, bgl3 $\beta$-glucosidase gene from the $A$. fumigatus $\mathrm{Z} 5$ has been expressed using the vector pPICZaA, leading to a 3.5-fold increment in BGL activity [151]. Jäger et al. [131] have been reported to express $T$. reese $i$ swollenin in Kluyveromyces lactis, and through microscopic observation, they found that swollenin regulates the breakdown of filter paper surface. Moreover, the crystallinity index of cellulose and filter paper has also been prevented by swollenin treatment. To improve the efficiency of a halostable cellulase isolated from marine A. niger, overexpression of EG and $\mathrm{CBH}$ genes was achieved through the promoter glaA and found $\mathrm{CBH}$ and $\mathrm{EG}$ activities improved from 0.21 and 4.51 to 0.89 and $15.12 \mathrm{U} / \mathrm{mL}$, respectively [43]. A thermostable $\mathrm{CBH}$ gene from Chaetomium thermophilum has been cloned and expressed in Pichia pastoris led to the production of thermotolerant $\mathrm{CBH}$, showing stability at $60{ }^{\circ} \mathrm{C}$ temperature and pH 5.0 [134]. Prabhu et al. [139] did similar work in $P$. pastoris and the resultant enzyme functions optimally at $60{ }^{\circ} \mathrm{C}$ in the $\mathrm{pH}$ range of $6.0-8.0$.

Codon optimization is an approach for enhanced protein production based on two facts; the degeneracy of genetic code and species-specific codon usage bias of most amino acids. Numerous efforts for substituting the host expression system's favored codons with the rare codons have been fruitful to fortify the heterologous expression [44]. The heterologous expression of codon-optimized Cel6A of $T$. reese $i$ was tenfold greater than the wild-type gene. Codon optimized egll of T. reese $i$ was expressed 1.24fold higher in $P$. pastoris [45]. T. reese $i$ having the synthetic cbh 2 gene construct exhibits a 2.02-fold increment in cellobiohydrolase activity as compared to the native $c b h 2$ gene [46]. Phadtare et al. [47] constructed a recombinant $P$. pastoris by cloning and constitutively expressing a codon-optimized endoglucanase gene from Myceliophthora thermophila (Mt-egl) and attained sugar yields of 421 and $382 \mathrm{mg} / \mathrm{g}$ by hydrolyzing wheat bran and corn cobs, respectively. Pei et al. [48] executed site-directed mutagenesis to exchange the rare codons for the N-terminal amino acids of the $b g l$ gene of Thermoanaerobacterium thermosaccharolyticum towards optimizing $b g l$ codons for expression in E. coli. The recombinant BGL activity amended to $11.2 \mathrm{U} / \mathrm{mg}$ from $6.6 \mathrm{U} / \mathrm{mg}$ and showed higher-level tolerance to glucose and cellobiose.

Directed evolution is a strategy utilized to design proteins with necessary potentialities. This technique simply imitates natural evolution, involves selecting the target gene with subsequent random mutagenesis or molecular recombination, which led to the construction of a library of mutant genes. Further screening of the mutants is done for desired characteristics [152]. Improved catalytic efficiency, 
thermostability, and glucose inhibition resistance of modified $\beta$-glucosidase (Ks5A7) was documented by Cao et al. [49] by substituting five amino acids in four cycles of random mutagenesis (through error-prone PCR). One and half fold improvement of specific activity of the enzyme was noticed with high glucose tolerance $\left(\mathrm{IC}_{50}\right.$ of $\left.1.5 \mathrm{M}\right)$. This mutant enzyme as a supplement with the Celluclast increased the glucose production by $44 \%$ following hydrolysis. Using the directed evolution strategy, Liu et al. [50] constructed a recombinant $E$. coli strain with a modified cellulase system, exhibiting an 8.2-fold rise in glucose yield compared to the cells armed with native enzymes. Here, the cbhA (exoglucanase gene from Cellulomonas fimi) mutant library fused with an expression vector (pET30a) carrying $b g l$ gene ( $\beta$-glucosidase from $T$. reesei) and transformed into Escherichia coli to form the entirely planned cellulase system. Using this strategy, Goedegebuur et al. [51] constructed a cellobiohydrolase I (Cel7A) from Hypocrea jecorina, which contained 18 mutated sites with a half-life 44 times better than the native form, and $10.4{ }^{\circ} \mathrm{C}$ rise of thermostability. A different version of $\beta$-glucosidase from the $A$. niger achieved through this tactic displayed $\mathrm{Tyr} \rightarrow \mathrm{Cys}$ substitution at 305 position. This point mutation led to a reduction in its transglycosylation activity, which otherwise inhibits its hydrolytic ability at high substrate concentrations [52].

Multiple gene expression is based on an evolutionary strategy, 'tandem gene duplication,' i.e., actually mimicking synthetic biology for enhanced protein expression. Recombinants obtained from genetically modified Aspergillus oryzae exhibit tenfold increment compared to the wild types (containing single gene) in cellulases activity. These were produced by integrating 5-10 copies of $\mathrm{cbh}$ or egl, or $b g l$ genes into their chromosomes [53]. Li et al. [54] produced genetically engineered recombinants of straw mushroom with 262 and $151 \%$ higher endoglucanase activity harboring four and eight copies of the gene $(\mathrm{egl})$ than the native hosts containing single and four copies, respectively.

The signal peptide sequence plays a crucial role in protein secretion. Substituting a potential signal peptide in a target protein tends to intensify its secretion efficiency [55]. Zhu et al. [56] increased EG activity (61.5\%) by exchanging the innate secretory signal sequence of the endoglucanase I (egl) gene by the $S$. cerevisiae $\operatorname{MF} \alpha$ ( $\alpha$-mating pheromone). A gene cassette of $\beta$-glucosidase ( $b g l l)$ and endoglucanase II (eglII) respectively from A. aculeatus and $T$. reesei was developed by Inokuma et al. [57] for cell surface display. The signal peptide sequences of the cassettes were derived from S. cerevisiae SED1 (SED1SP), Rhizopus oryzae glucoamylase (GLUASP), and $S$. cerevisiae $\alpha$-mating pheromone (MF $\alpha 1 \mathrm{SP})$. The modified strains with the SED1SP displayed 1.3- and 1.9-fold higher $\beta$-glucosidase activity than the GLUASP and MF $\alpha 1$ SP strains, respectively. No significant change in extracellular endoglucanase activity of modified strains with the SED1SP and MF $\alpha 1 S P$ was noticed. The efficiency of engineered signal peptides is limited, not advantageous for all heterologous proteins [58]. Thus, identification of target protein-specific secretory fusion partner is mandatory. In yeast, for the poorly secreted proteins, an innovative protein secretion system was established based on the yeast genome-arrayed secretion leader library for searching the protein-specific translational fusion partners [58]. The degree of secretion and hydrolytic potential of Chrysosporium lucknowense cbh2 were increased 2.4- and 1.4-fold than the native signal peptide (NSP) and MF $\alpha$, respectively. The enzymatic activity of boll of Saccharomycopsis fibuligera was also 4.3- and 39.9-times higher than the protein secreted by the NSP and MF $\alpha$, respectively [59].

Correct protein folding is one of the many prerequisites to protein secretion-molecular chaperon act to preserve nascent proteins in a folding-competent conformation and prevent aggregation. Therefore, chaperones engineering is an efficient tool for improving enzyme activity [60]. Tang et al. [61] observed a 53\% rise in the specific activity of $\beta$-glucosidase of recombinant Saccharomyces cerevisiae strains than the wild type, resulting from overexpression of chaperone protein disulfide isomerase (Pdi1p) of endoplasmic reticulum. In a similar study Li et al. [54] documented increased folding and secretion of the recombinant endoglucanase in Pichia pastoris of up to $619 \%(91 \mathrm{U} / \mathrm{mL})$, resulting from the overexpression of the key transcription factor HAC1 that controls the unfolded protein response. Yang et al. [62] cloned $\beta$-glucosidase ( $b g l$ ) of Thermoanaerobacterium aotearoense together with a chaperone (groESgroEL) in E. coli. The recombinants exhibited a 9.2-fold better specific enzyme activity than the chaperone deficient strains.

Engineering of vesicle trafficking-related components is another strategy to facilitate heterologous protein expression, supporting the increment in cellulolytic efficiency. By overexpressing specific Soluble N-ethylmaleimide-sensitive factor Attachment Receptor (SNAREs) genes (responsible for encoding small membrane proteins that coordinate intracellular protein trafficking from Golgi to the cell membrane) in a recombinant strain of S. cerevisiae, resulting in enhanced secretion of its cellobiohydrolase (Cel7A) and $\beta$-glucosidase (Cel3A) isolated from Talaromyces emersonii, and Saccharomycopsis fibuligera, respectively [63]. The concurrent over-expression of the exocytic SNARE complex components having different combinations of Snc1/2, Sso1/2, and Sec9 genes led to the $52 \%$ and $49 \%$ increment in the secretion of Cel7 A and Cel3A, respectively.

Trimming of glycosylation for improved cellulase yield is a new field of metabolic engineering [64]. As per rule, the $\mathrm{N}$-glycosylation is a specific feature of catalytic domains (CD), whereas the peptide linkers, copious with serine 
and threonine residues, are thoroughly ornamented with O-linked glycans [65]. N-linked glycosylation is the addition of glycan (an oligosaccharide) to amide nitrogen of asparagine residue of a protein. Glycosylation is also recognized to modulate binding to cellulose as well as lignin [66]. Adney et al. [67] observed 85\% enhancement cellobiohydrolase-1 activity by adding an N-glycan on Penicillium funiculosum Cel7A at asparagine-194 (N194). Adney et al. [67] also reported that during expression of T. reesei Cel7A in A. niger var. awamori, removal of an $\mathrm{N}$-glycosylation site (N384) resulted in a mutant strain with $70 \%$ higher activity than the Cel7A expressed in $T$. reesei. The deglycosylation of $T$. reesei Cel7A, resulting in the decline of enzyme stability [68]. Payne et al. [153] revealed that O-glycosylated cellulase linkers take part in cellulose-binding affinity, therefore, the O-glycans may be indispensable for cellulose binding [69] found that the addition of O-glycans resulted in improved thermostability, and cellulose-binding affinity of family 1 CBM. Wei et al. [154] studied the effect of four $\mathrm{N}$-glycosylation sites (N224, NN295, N363, and N429) on the Aspergillus terreus $\beta$-glucosidase activity through heterologous expression in P. pastoris and T. reesei, and observed that the mutation on those sites of $\mathrm{N}$-glycosylation led to reduced activity and thermostability.

CRISPR is chiefly a bacterial/archaeal immunity mechanism active against bacteriophage attacks. It is now applying as a powerful genome-editing technology [70]. The CRISPR system is broadly classified into two major classes: the class I system, which needs multiple effector proteins, while the class II system needs only single effector proteins. The class II system has either Cas9 or Cpf1 endonuclease [71]. The class II CRISPR system of Streptococcus thermophilus and Streptococcus pyogenes utilize a simple tactic using specific $\operatorname{Cas} 9$ nucleases dependent on the species-oriented RNA-based adaptive immunity mechanism [72]. The single guide RNA (sgRNA), an amalgamation of crRNA (CRISPRderived RNA) and tracer RNA (trans-activating CRISPR RNA), determines the target of Cas9. Cas9 identifies and cleaves the target DNA sequence based on sgRNA [16]. The sgRNA, which identifies a 20-nucleotide sequence located upstream of the protospacer adjacent motif (PAM), is fabricated as per the specific target of choice. Therefore, any preferred gene can be inserted or deleted through host repair mechanisms (i.e., homologous recombination and nonhomologous end-joining DNA), which quickly respond to Cas9 nucleases (Fig. 3). The Cas9 protein comprises of two domains: RuvC, which cleaves the DNA sequence non-complementary to the crRNA; whereas another domain, $\mathrm{HNH}$ cleaving the DNA strand complementary to the CRISPR RNA [73, 74]. Due to the marginal level of off-target effects, therefore, the Cas9 gene is extensively used in CRISPR technology [75]. The optimistic expression of Cas9 relies on the type of promoter. Hence, selecting an appropriate promoter is highly recommended for the CRISPR/Cas9 system [73]. In filamentous fungi, trpC, gpdA, and tef1 promoters derived from A. nidulans are often utilized [76, 77]. The Cas9 gene design is based on the bacterial or archaeal immune system, therefore, codon optimization is compulsory. Additionally, for utilizing this system in filamentous fungi, a specific signal sequence known as the nuclear localization sequence (NLS from SV40 is fused to either one end or both the end of Cas 9 to import it to the nucleus through the nuclear translocation system [78]. Further, it plays a significant role in protein stability and checks outflow through nuclear pores [79]. A proficient CRISPR/Cas9 system is dependent on the expression of sgRNA. The sgRNA comprises no suitable CAP structure or poly (A) tail and cannot be adequately transcribed by the type II RNA polymerase. Due to a welldefined transcription site, the U6 promoters of type III RNA polymerase are often used in most filamentous fungi to express the sgRNA in the CRISPR/Cas9 system [80, 81]. However, there are some restrictions in utilizing the U6 promoters, for example, U6 snRNA are housekeeping genes ubiquitously expressed; thus, they cannot produce tissue-specific gRNA. Since RNA polymerase III is commercially not obtainable, U6 promoters are not appropriate for in vitro transcription of gRNA. Additionally, the CRISPR target sequences recognized by the U6 promoter have certain sequence specificity $\left[\mathrm{G}(\mathrm{N})_{20} \mathrm{GG}\right][82,83]$. Regarding this, both in vitro and in vivo approaches are applicable to express gRNA. One of the recently established approaches is constructing an efficient sgRNA expression system containing a 338-bp promoter sequence derived from the $5 \mathrm{~S}$ rRNA gene of $A$. niger utilizing the sgRNA sequence as an expression cassette. An additional 88-bp sequence from Trichoderma atroviride was ligated between sgRNA and 5S rRNA to get off RNA interference [82, 84]. The CRISPR/ Cas9 system having such a promoter for expressing sgRNA has been more efficient than U6 promoters [73] (Zheng et al. 2019). DSBs made by Cas9 can directly undergo indel mutagenesis by nonhomologous end-joining repair (NHEJ), or homology repair (HR) can be attained if a template for DNA repair is supplied $[85,86]$. The poorly precise NHEJ repair occurs during the G1 phase of the cell cycle, while the exact HR repair pathway occurs only during the $S$ phase. The ku70 and ku 80 proteins mediated NHEJ repair pathways can be directly associated with the ends of the DSBs. The HR repair pathway requires a target site for homologous donor DNA fragments [87]. Additionally, the chance of HR repair will surge by around 1000 times if there are proximate homologous DNA fragments during DNA damage repair [73]. Therefore, an efficient CRISPR/Cas9 system can utilize the HR pathway for precise target editing, such as initiating specific point mutations at target sites, inserting a preferred sequence, or precisely substituting a sequence with the preferred sequence [88]. Liu et al. [89] constructed a CRISPR/ 


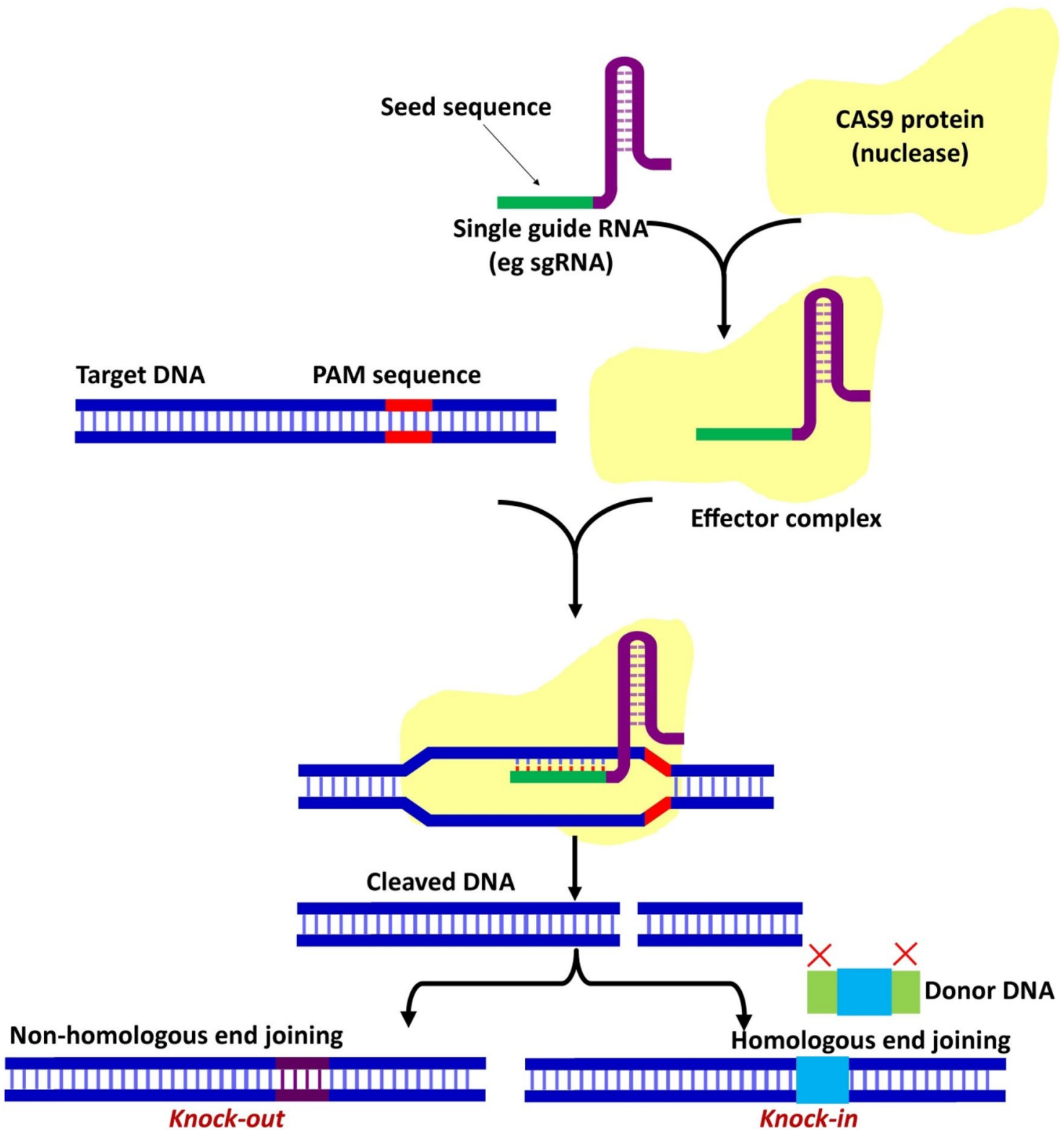

Fig. 3 Basic mechanism of CRISPR-CAS9 system

Cas9 system in $T$. reesei by introducing homologous arms of altered sizes to the left and right side of the selectable marker and revealed that the addition of this $\geq 600$-bp homology arm around the selectable marker led to the $100 \%$ frequency of homologous recombination, facilitating CRISPR/Cas9oriented gene knockout in $T$. reesei. Compared to the traditional genetic engineering strategies applied in filamentous fungi, the CRISPR-Cas9 system has several advantages. (a) It is simple in operation: a similar CAS9 can be applied to target different genes by altering the only sgRNA. (b) It is efficient: This system is applicable for quick manipulation of a single gene and used to amend multiple sites simultaneously. (c) It is flexible: it allows marker-free strain production, therefore assisting metabolic engineering of the strain by handling several genes. (d) It is non-toxic: No difference was observed in cell growth and sporulation when cells expressed Cas9 [90]. Matsu-Ura et al. [76] have been successfully executed CRISPR/Cas9 mediated genetic engineering of the filamentous fungus $N$. crass $a$, where the cas 9 gene expressed under the control of the trpC promoter and terminator region from $A$. nidulans after incorporation into the genome of $N$. crassa. They utilize Cas 9 endonuclease and single crRNA: tracrRNA chimeric guide RNA to place the $c l r-2$ gene under the control of a $\beta$-tubulin promoter, leading to approximately 200 -fold increment in $c l r-2$ mRNA expression than the wild type strain, which subsequently 
amplified the cellulase genes' expression. The $c b h-1, g h 5-1$ $(e g l)$, and $g h 6-2(c b h)$ mRNA expression levels augmented to $68.3,1724.3$ and 14.6 fold, respectively. Following this strategy, Liu et al. [90] engineered Myceliophthora thermophila and $M$. heterothallica strains having significantly greater potential of cellulase production. Multigene disruption of the cellulase production-related genes (cre-1, res- 1 , ghl-1, and alp-1) led to hypercellulase yield up to 5-13-fold. Abolition of cre-1 gene from M. thermophila (1Mtcre-1) led to 3.7-fold additional protein secretion in avicel medium. Likewise, $M$. heterothallica mutant (1Mhcre-1) exhibited a noticeable enhancement in activity of cellulase and their degree of secretion. According to this technique, an engineered $S$. cerevisiae was created by incorporating 'sestc expression cassettes' having glyceraldehyde-3-phosphatedehydrogenase gene promoter of Agaricus bisporus [91]. The endo-1,4- $\beta$-glucanase and exo-1,4- $\beta$-glucanase activities of the recombinants were 35.3 and 23 -fold higher than the wild-type $S$. cerevisiae.

Cpf1 (previously Cas 12a) denotes CRISPR-linked endonuclease derived from Prevotella and Francisella. Recently it gained more attention to the research fraternity as an emerging genome-editing tool that efficiently substitutes the CRISPR-Cas9 system [92]. It has several distinctive features compared to the CRISPR-CAS9 system. Cpf1 performed as a dual nuclease: as an endodeoxyribonuclease to cut target DNA and as endoribonuclease to process its own crRNA. It acts as a single RNA-guided endonuclease having only a short 42-44 nt long crRNA (lacking transencoded-crRNA) that identifies a thymidine-rich PAM at the 5 '-side of the target site and introduces staggered cuts, resulting in a $5^{\prime}$-overhang distal to the PAM site. While, CAS9 endonuclease needs both $100 \mathrm{nt}$ long crRNA and tracrRNA, recognizing guanine-rich PAM at the 3'-side of the target side and subsequently introducing blunt cut $[92,93]$. Unlike Cas9 endonuclease, which has both the RuvC and $\mathrm{HNH}$ domains, the $\mathrm{Cpf} 1$ endonuclease comprises only the RuvC domain [92, 94]. Besides, Cpf1 permits multiplexed genome editing through its single crRNA array transcript that can target multiple loci in the genome [93]. For example, Abdulrachman et al. [92] showed that Cpf1 (FnCpf1) isolated from Francisella tularensis, introduced site-specific double-strand breaks at the pyrG gene in A. aculeatus TBRC 277, a potential enzyme synthesizing manufacturing hub. Thus, this strategy facilitates site-specific insertion or deletion followed by NHEJ.

To diversify the applicable potentiality of the CRISPRCAS system, it is modified to a multiplexed CRISPR system that allows genome editing along with transcriptional regulation at multiple targets. Based on the catalytically inactive forms of Cas9 (dCas9) and $\mathrm{Cpf} 1 \mathrm{dCpf1)}$, the traditional CRISPR-CAS system modified for activation of gene expression (CRISPRa) and gene interference (CRISPRi) [15, 95].
The catalytically inactive dCas9 have two point mutations in the RuvC and $\mathrm{HNH}$ nuclease domains, while the inactive dCfp1 has mutation only in the RuvC domain. Although such mutations inactivate the endonuclease activity of the CAS9 or Cpf1, they do not intervene in their normal binding to the guide RNA and subsequent interaction with the targets $[15,94]$. By fusing to the appropriate transcriptional activators, the target-guiding skill of the CAS9 or Cpf1 endonucleases are utilized for gene activation, while the catalytically inactive enzymes after fusing to a repressor domain leading to transcriptional repression. Such approaches might benefit gene regulation in fungi, especially for multi-nucleated fungi and specific RNAi machinery deficient ascomycetes and basidiomycetes species [73]. Therefore, the CRISPRa and CRISPRi might be exploited for enhancing fungal metabolic pathways by concurrently activating or repressing genes that participated in targeted metabolic pathways [95].

\section{Conclusion and prospects}

Over the previous few decades, significant progress was observed in cellulase production, supporting a wide array of industrial purposes. Globally, cellulase apprises its market eligibility, drawing attention to developed and under-developed countries to implement a research strategy towards its commercial scale of production. Fungi being an inherent efficient producer and extracellular secretor of cellulases, is gaining intense research attention. Developing a fungal strain of improved cellulase activity with inexpensive production cost is the principal criterion of present cellulase research.

The varieties of biological systems' complexities may obstruct the pathway for designing novel approaches to support cellular potentialities for improving cellulase production. Advancement in systems biology and synthetic biology contributes to novel targets and ideas for the hyperproduction of cellulase by fungal strains. Competent genetic manipulation approaches have been developed from time to time to engineer filamentous fungi, and among these approaches, CRISPR/CAS system is most acceptable. At present, in fungi, the CRISPR/CAS technology has been providing varieties of applications: gene silencing, producing mutant, improvement of secondary metabolites, gene overexpression, gene regulation, gene tagging, and so on. However, there are still certain limitations in the applicability of this technology, such as the off-target effect, requirement in improving editing efficiency, and building an operational carrier system for several fungi. The progressive improvement in the CRISPR/Cas technology plays an indispensable role in the genetic modification of filamentous fungi in future research. Newish approaches of transcriptomics, fluxomics, metabolomics, and proteomics allow the innovative 
concepts for the improved production of cellulase and make it an important tool for the sustainable development of modern human civilization.

\section{References}

1. Baruah J, Nath BK, Sharma R, Kumar S, Deka RC, Baruah DC, Kalita E. Recent trends in the pretreatment of lignocellulosic biomass for value-added products. Front Energy Res. 2018;18(6): 141 .

2. Das A, Paul T, Halder SK, Das Mohapatra PK, Pati BR, Mondal KC. Study on regulation of growth and biosynthesis of cellulolytic enzymes from newly isolated Aspergillus fumigatus ABK9. Pol J Microbiol. 2013;62(1):31-43.

3. Das A, Paul T, Halder SK, Jana A, Ghosh K, Maity C, Das Mohapatra PK, Pati BR, Mondal KC. Low cost single-step purification of endoglucanase from Aspergillus fumigates ABK9. Ind J Exp Biol. 2013;51(11):954-9.

4. Park S, Baker JO, Himmel ME, Parilla PA, Johnson DK. Cellulose crystallinity index: measurement techniques and their impact on interpreting cellulase performance. Biotechnol Biofuels. 2010;3(1):1.

5. Wang BT, Hu S, Yu XY, Jin L, Zhu YJ, Jin FJ. Studies of cellulose and starch utilization and the regulatory mechanisms of related enzymes in fungi. Polymers. 2020;12(3):530.

6. Mondal S, Halder SK, Mondal KC. Fungal enzymes for bioconversion of lignocellulosic biomass. In: Yadav AN, Singh S, Mishra S, Gupta A, editors. Recent advancement in white biotechnology through fungi. Cham: Springer; 2019. p. 349-80.

7. Das A, Jana A, Paul T, Halder SK, Ghosh K, Maity C, Das Mohapatra PK, Pati BR, Mondal KC. Thermodynamics and kinetic properties of halostable endoglucanase from Aspergillus fumigatus ABK9. J Basic Microbiol. 2014;54:S142-51.

8. Mondal S, Soren JP, Mondal J, Rakshit S, Halder SK, Mondal KC. Contemporaneous synthesis of multiple carbohydrate debranching enzymes from newly isolated Aspergillus fumigatus SKF-2 under solid state fermentation: a unique enzyme mixture for proficient saccharification of plant bioresources. Ind Crops Prod. 2020;150: 112409

9. Zhao XQ, Zhang XY, Zhang F, Zhang R, Jiang BJ, Bai FW. Metabolic engineering of fungal strains for efficient production of cellulolytic enzymes. In: Xu F, Qu Y, editors. Fungal cellulolytic enzymes. Singapore: Springer; 2018. p. 27-41.

10. Das A, Paul T, Halder SK, Jana A, Maity C, Das Mohapatra PK, Pati BR, Mondal KC. Production of cellulolytic enzymes by Aspergillus fumigatus $\mathrm{ABK} 9$ in wheat bran-rice straw mixed substrate and use of cocktail enzymes for deinking of waste office paper pulp. Bioresour Technol. 2013;128:290-6.

11. Chandel AK, Rudravaram R, Rao LV, Ravindra P, Narasu ML. Industrial enzymes in bioindustrial sector development: an Indian perspective. J Commer Biotechnol. 2007;13(4):283-91.

12. Jayasekara S, Ratnayake R. Microbial cellulases: an overview and applications. Cellulose. 2019. https://doi.org/10.5772/intec hopen.84531.

13. de França PD, Pereira N Jr, de Castro AM. A comparative review of recent advances in cellulases production by Aspergillus, Penicillium and Trichoderma strains and their use for lignocellulose deconstruction. Curr Opin Green Sustain Chem. 2018;14:60-6.

14. Adebami GE, Adebayo-Tayo BC. Development of cellulolytic strain by genetic engineering approach for enhanced cellulase production. In: Kuila A, Sharma V, editors. Genetic and metabolic engineering for improved biofuel production from lignocellulosic biomass. 1st ed. Elsevier; 2020. p. 103-36.
15. McCarty NS, Graham AE, Studená L, Ledesma-Amaro R. Multiplexed CRISPR technologies for gene editing and transcriptional regulation. Nat Commun. 2020;11(1):1-13.

16. Sukumaran RK, Christopher M, Kooloth-Valappil P, SreejaRaju A, Mathew RM, Sankar M, Puthiyamadam A, Adarsh VP, Aswathi A, Rebinro V, Abraham A. Addressing challenges in production of cellulases for biomass hydrolysis: targeted interventions into the genetics of cellulase producing fungi. Bioresour Technol. 2021;329: 124746.

17. Patel AK, Singhania RR, Sim SJ, Pandey A. Thermostable cellulases: current status and perspectives. Bioresour Technol. 2019;279:385-92.

18. Singhania RR, Dixit P, Patel AK, Giri BS, Kuo CH, Chen CW, Di Dong C. Role and significance of lytic polysaccharide monooxygenases (LPMOs) in lignocellulose deconstruction. Bioresour Technol. 2021;335: 125261.

19. Müller G, Chylenski P, Bissaro B, Eijsink VG, Horn SJ. The impact of hydrogen peroxide supply on LPMO activity and overall saccharification efficiency of a commercial cellulase cocktail. Biotechnol Biofuels. 2018;11(1):1-7.

20. Zhang F, Bunterngsook B, Li JX, Zhao XQ, Champreda V, Liu $\mathrm{CG}$, Bai FW. Regulation and production of lignocellulolytic enzymes from Trichoderma reesei for biofuels production. In: Li Y, Ge X, editors. Advances in bioenergy, vol. 4. Elsevier; 2019. p. 79-119.

21. Baker JO, King MR, Adney WS, Decker SR, Vinzant TB, Lantz SE, Nieves RE, Thomas SR, Li LC, Cosgrove DJ, Himmel ME. Investigation of the cell-wall loosening protein expansin as a possible additive in the enzymatic saccharification of lignocellulosic biomass. In: Finkelstein M, Davison BH, editors. Twenty-first symposium on biotechnology for fuels and chemicals. 1st ed. Totowa: Humana Press; 2000. p. 217-23.

22. Andberg M, Penttilä M, Saloheimo M. Swollenin from Trichoderma reesei exhibits hydrolytic activity against cellulosic substrates with features of both endoglucanases and cellobiohydrolases. Bioresour Technol. 2015;181:105-13.

23. Druzhinina IS, Kubicek CP. Genetic engineering of Trichoderma reesei cellulases and their production. Microb Biotechnol. 2017;10(6):1485-99.

24. da Silva Delabona P, Rodrigues GN, Zubieta MP, Ramoni J, Codima CA, Lima DJ, Farinas CS, da Cruz Pradella JG, Seiboth B. The relation between xyrl overexpression in Trichoderma harzianum and sugarcane bagasse saccharification performance. $\mathrm{J}$ Biotechnol. 2017;246:24-32.

25. Derntl C, Gudynaite-Savitch L, Calixte S, White T, Mach RL, Mach-Aigner AR. Mutation of the xylanase regulator 1 causes a glucose blind hydrolase expressing phenotype in industrially used Trichoderma strains. Biotechnol Biofuels. 2013;6(1):1-1.

26. Ellilä S, Fonseca L, Uchima C, Cota J, Goldman GH, Saloheimo M, Sacon V, Siika-Aho M. Development of a low-cost cellulase production process using Trichoderma reesei for Brazilian biorefineries. Biotechnol Biofuels. 2017;10(1):1-7.

27. Rassinger A, Gacek-Matthews A, Strauss J, Mach RL, MachAigner AR. Truncation of the transcriptional repressor protein Cre1 in Trichoderma reesei Rut-C30 turns it into an activator. Fungal Biol Biotechnol. 2018;5(1):1-8.

28. Zhang XY, Zi LH, Ge XM, Li YH, Liu CG, Bai FW. Development of Trichoderma reesei mutants by combined mutagenesis and induction of cellulase by low-cost corn starch hydrolysate. Process Biochem. 2017;54:96-101.

29. Wang S, Liu G, Wang J, Yu J, Huang B, Xing M. Enhancing cellulase production in Trichoderma reesei RUT C30 through combined manipulation of activating and repressing genes. J Ind Microbiol Biotechnol. 2013;40(6):633-41.

30. Wang S, Liu G, Yu J, Tian S, Huang B, Xing M. RNA interference with carbon catabolite repression in Trichoderma koningii 
for enhancing cellulase production. Enzyme Microb Technol. 2013;53(2):104-9.

31. Zhang F, Zhao X, Bai F. Improvement of cellulase production in Trichoderma reesei Rut-C30 by overexpression of a novel regulatory gene Trvib-1. Bioresour Technol. 2018;247:676-83.

32. Zhang J, Wu C, Wang W, Wei D. Construction of enhanced transcriptional activators for improving cellulase production in Trichoderma reesei RUT C30. Bioresour Bioprocess. 2018;5(1):1-2.

33. Xiong Y, Sun J, Glass NL. VIB1, a link between glucose signaling and carbon catabolite repression, is essential for plant cell wall degradation by Neurospora crassa. PLoS Genet. 2014;10(8): e1004500.

34. Zhang J, Zhang G, Wang W, Wei D. Enhanced cellulase production in Trichoderma reesei RUT C30 via constitution of minimal transcriptional activators. Microb Cell Fact. 2018;17(1):1-4.

35. Li Y, Zhang X, Xiong L, Mehmood MA, Zhao X, Bai F. On-site cellulase production and efficient saccharification of corn stover employing $c b h 2$ overexpressing Trichoderma reese $i$ with novel induction system. Bioresour Technol. 2017;238:643-9.

36. Kiesenhofer DP, Mach RL, Mach-Aigner AR. Influence of cis element arrangement on promoter strength in Trichoderma reesei. Appl Environ Microbiol. 2018;84(1): e1742-17.

37. Hirasawa H, Shioya K, Furukawa T, Tani S, Sumitani JI, Kawaguchi T, Morikawa Y, Shida Y, Ogasawara W. Engineering of the Trichoderma reesei xylanase 3 promoter for efficient enzyme expression. Appl Microbiol Biotechnol. 2018;102(6):2737-52.

38. Wang W, Meng F, Liu P, Yang S, Wei D. Construction of a promoter collection for genes co-expression in filamentous fungus Trichoderma reesei. J Ind Microbiol Biotechnol. 2014;41(11):1709-18.

39. Alriksson B, Rose SH, Van-Zyl WH, Sjöde A, Nilvebrant NO, Jönsson LJ. Cellulase production from spent lignocellulose hydrolysates by recombinant Aspergillus niger. Appl Environ Microbiol. 2009;75(8):2366-74.

40. Hong J, Tamaki H, Yamamoto K, Kumagai H. Cloning of a gene encoding thermostable cellobiohydrolase from Thermoascus aurantiacus and its expression in yeast. Appl Microbiol Biotechnol. 2003;63(1):42-50.

41. Bulakhov AG, Volkov PV, Rozhkova AM, Gusakov AV, Nemashkalov VA, Satrutdinov AD, Sinitsyn AP. Using an inducible promoter of a gene encoding Penicillium verruculosum glucoamylase for production of enzyme preparations with enhanced cellulase performance. PLoS ONE. 2017;12(1): e0170404.

42. Yao G, Li Z, Gao L, Wu R, Kan Q, Liu G, Qu Y. Redesigning the regulatory pathway to enhance cellulase production in Penicillium oxalicum. Biotechnol Biofuels. 2015;8(1):1-7.

43. Xue D, Lin D, Gong C, Peng C, Yao S. Expression of a bifunctional cellulase with exoglucanase and endoglucanase activities to enhance the hydrolysis ability of cellulase from a marine Aspergillus niger. Process Biochem. 2017;52:115-22.

44. Quax TE, Claassens NJ, Söll D, van der Oost J. Codon bias as a means to fine-tune gene expression. Mol Cell. 2015;59(2):149-61.

45. Akcapinar GB, Gul O, Sezerman U. Effect of codon optimization on the expression of Trichoderma reesei endoglucanase I in Pichia pastoris. Biotechnol Prog. 2011;27(5):1257-63.

46. Fang H, Xia L. Heterologous expression and production of Trichoderma reesei cellobiohydrolase II in Pichia pastoris and the application in the enzymatic hydrolysis of corn stover and rice straw. Biomass Bioenergy. 2015;78:99-109.

47. Phadtare P, Joshi S, Satyanarayana T. Recombinant thermoalkali-stable endoglucanase of Myceliopthora thermophila BJA (rMt-egl): biochemical characteristics and applicability in enzymatic saccharification of agro-residues. Int J Biol Macromol. 2017;104:107-16.
48. Pei J, Pang Q, Zhao L, Fan S, Shi H. Thermoanaerobacterium thermosaccharolyticum $\beta$-glucosidase: a glucose-tolerant enzyme with high specific activity for cellobiose. Biotechnol Biofuels. 2012;5(1):1.

49. Cao L, Li S, Huang X, Qin Z, Kong W, Xie W, Liu Y. Enhancing the thermostability of highly active and glucose-tolerant $\beta$-glucosidase Ks5A7 by directed evolution for good performance of three properties. J Agric Food Chem. 2018;66(50):13228-35.

50. Liu M, Xie W, Xu H, Gu J, Lv X, Yu H, Ye L. Directed evolution of an exoglucanase facilitated by a co-expressed $\beta$-glucosidase and construction of a whole engineered cellulase system in Escherichia coli. Biotechnol Lett. 2014;36(9):1801-7.

51. Goedegebuur F, Dankmeyer L, Gualfetti P, Karkehabadi S, Hansson H, Jana S, Huynh V, Kelemen BR, Kruithof P, Larenas EA, Teunissen PJ. Improving the thermal stability of cellobiohydrolase Cel7A from Hypocrea jecorina by directed evolution. J Biol Chem. 2017;292(42):17418-30.

52. Larue K, Melgar M, Martin VJ. Directed evolution of a fungal $\beta$-glucosidase in Saccharomyces cerevisiae. Biotechnol Biofuels. 2016;9(1):1-5.

53. Wakai S, Nakashima N, Ogino C, Tsutsumi H, Hata Y, Kondo A. Modified expression of multi-cellulases in a filamentous fungus Aspergillus oryzae. Bioresour Technol. 2019;276:146-53.

54. Li L, Huang C, Zhao F, Deng T, Lin Y, Zheng S, Liang S, Han S. Improved production and characterization of Volvariella volvacea Endoglucanase 1 expressed in Pichia pastoris. Protein Expr Purif. 2018;152:107-13.

55. Wang Q, Zhong C, Xiao H. Genetic engineering of filamentous fungi for efficient protein expression and secretion. Front Bioeng Biotechnol. 2020;8:293.

56. Zhu H, Yao S, Wang S. MFo signal peptide enhances the expression of cellulase egl gene in yeast. Appl Biochem Biotechnol. 2010;162(3):617-24.

57. Inokuma $\mathrm{K}$, Bamba $\mathrm{T}$, Ishii J, Ito $\mathrm{Y}$, Hasunuma $\mathrm{T}$, Kondo A. Enhanced cell-surface display and secretory production of cellulolytic enzymes with Saccharomyces cerevisiae Sed1 signal peptide. Biotechnol Bioeng. 2016;113(11):2358-66.

58. Bae JH, Sung BH, Kim HJ, Park SH, Lim KM, Kim MJ, Lee $\mathrm{CR}$, Sohn JH. An efficient genome-wide fusion partner screening system for secretion of recombinant proteins in yeast. Sci Rep. 2015;5(1):1-5.

59. Dadwal A, Sharma S, Satyanarayana T. Progress in ameliorating beneficial characteristics of microbial cellulases by genetic engineering approaches for cellulose saccharification. Front Microbiol. 2020;2020:11.

60. Xiao S, Shiloach J, Betenbaugh MJ. Engineering cells to improve protein expression. Curr Opin Struct Biol. 2014;26:32-8.

61. Tang H, Bao X, Shen Y, Song M, Wang S, Wang C, Hou J. Engineering protein folding and translocation improves heterologous protein secretion in Saccharomyces cerevisiae. Biotechnol Bioeng. 2015;112(9):1872-82.

62. Yang F, Yang X, Li Z, Du C, Wang J, Li S. Overexpression and characterization of a glucose-tolerant $\beta$-glucosidase from T. aotearoense with high specific activity for cellobiose. Appl Microbiol Biotechnol. 2015; 99(21):8903-15.

63. Van Zyl JH, Den Haan R, Van Zyl WH. Over-expression of native Saccharomyces cerevisiae exocytic SNARE genes increased heterologous cellulase secretion. Appl Microbiol Biotechnol. 2014;98(12):5567-78.

64. Kuhad RC, Deswal D, Sharma S, Bhattacharya A, Jain KK, Kaur A, Pletschke BI, Singh A, Karp M. Revisiting cellulase production and redefining current strategies based on major challenges. Renew Sustain Energ Rev. 2016;55:249-72.

65. Greene ER, Himmel ME, Beckham GT, Tan Z. Glycosylation of cellulases: engineering better enzymes for biofuels. Adv Carbohydr Chem Biochem. 2015;72:63-112. 
66. Chung D, Sarai NS, Knott BC, Hengge N, Russell JF, Yarbrough JM, Brunecky R, Young J, Supekar N, Vander Wall T, Sammond DW. Glycosylation is vital for industrial performance of hyperactive cellulases. ACS Sustain Chem Eng. 2019;7(5):4792-800.

67. Adney WS, Jeoh T, Beckham GT, Chou YC, Baker JO, Michener W, Himmel ME. Probing the role of N-linked glycans in the stability and activity of fungal cellobiohydrolases by mutational analysis. Cellulose. 2009;16(4):699-709.

68. Gupta R, Baldock SJ, Fielden PR, Grieve BD. Capillary zone electrophoresis for the analysis of glycoforms of cellobiohydrolase. J Chromatogr A. 2011;1218(31):5362-8.

69. Guan X, Chaffey PK, Zeng C, Greene ER, Chen L, Drake MR, Chen C, Groobman A, Resch MG, Himmel ME, Beckham GT. Molecular-scale features that govern the effects of O-glycosylation on a carbohydrate-binding module. Chem Sci. 2015;6(12):7185-9.

70. Ullah M, Xia L, Xie S, Sun S. CRISPR/Cas9-based genome engineering: a new breakthrough in the genetic manipulation of filamentous fungi. Biotechnol Appl Biochem. 2020;67(6):835-51.

71. Bai SK, Hong Y, Wu YR. Emerging technologies for genetic modification of solventogenic clostridia: from tool to strategy development. Bioresour Technol. 2021;334: 125222.

72. Ishino Y, Krupovic M, Forterre P. History of CRISPR-Cas from encounter with a mysterious repeated sequence to genome editing technology. J Bacteriol. 2018;200(7):e00580-e617.

73. Song R, Zhai Q, Sun L, Huang E, Zhang Y, Zhu Y, Guo Q, Tian Y, Zhao B, Lu H. CRISPR/Cas9 genome editing technology in filamentous fungi: progress and perspective. Appl Microbiol Biotechnol. 2019;103(17):6919-32.

74. Sternberg SH, Redding S, Jinek M, Greene EC, Doudna JA. DNA interrogation by the CRISPR RNA-guided endonuclease Cas9. Nature. 2014;507(7490):62-7.

75. Yao R, Liu D, Jia X, Zheng Y, Liu W, Xiao Y. CRISPR-Cas9/ Cas12a biotechnology and application in bacteria. Synth Syst Biotechnol. 2018;3(3):135-49.

76. Matsu-Ura T, Baek M, Kwon J, Hong C. Efficient gene editing in Neurospora crassa with CRISPR technology. Fungal Biol Biotechnol. 2015;2(1):1-7.

77. Zhang C, Meng X, Wei X, Lu L. Highly efficient CRISPR mutagenesis by microhomology-mediated end joining in Aspergillus fumigatus. Fungal Genet Biol. 2016;86:47-57.

78. Deng H, Gao R, Liao X, Cai Y. CRISPR system in filamentous fungi: current achievements and future directions. Gene. 2017;627:212-21.

79. Wang Q, Coleman JJ. Progress and challenges: development and implementation of CRISPR/CAS9 technology in filamentous fungi. Comput Struct Biotechnol J. 2019;17:761-9.

80. Katayama T, Tanaka Y, Okabe T, Nakamura H, Fujii W, Kitamoto $\mathrm{K}$, Maruyama JI. Development of a genome editing technique using the CRISPR/Cas9 system in the industrial filamentous fungus Aspergillus oryzae. Biotechnol Lett. 2016;38(4):637-42.

81. Shi TQ, Liu GN, Ji RY, Shi K, Song P, Ren LJ, Huang H, Ji XJ. CRISPR/Cas9-based genome editing of the filamentous fungi: the state of the art. Appl Microbiol Biotechnol. 2017;101(20):7435-43.

82. Gao Y, Zhao Y. Self-processing of ribozyme-flanked RNAs into guide RNAs in vitro and in vivo for CRISPR-mediated genome editing. J Integr Plant Biol. 2014;56(4):343-9.

83. Nissim L, Perli SD, Fridkin A, Perez-Pinera P, Lu TK. Multiplexed and programmable regulation of gene networks with an integrated RNA and CRISPR/Cas toolkit in human cells. Mol Cell. 2014;54(4):698-710.

84. Zheng X, Zheng P, Zhang K, Cairns TC, Meyer V, Sun J, Ma Y. 5S rRNA promoter for guide RNA expression enabled highly efficient CRISPR/Cas9 genome editing in Aspergillus niger. ACS Synth Biol. 2018;8(7):1568-74.
85. Ma X, Zhu Q, Chen Y, Liu YG. CRISPR/Cas9 platforms for genome editing in plants: developments and applications. Mol Plant. 2016;9(7):961-74.

86. Shalem O, Sanjana NE, Zhang F. High-throughput functional genomics using CRISPR-Cas9. Nat Rev Genet. 2015;16(5):299-311.

87. Branzei D, Foiani M. Regulation of DNA repair throughout the cell cycle. Nat Rev Mol Cell Biol. 2008;9(4):297-308.

88. Feng Z, Mao Y, Xu N, Zhang B, Wei P, Yang DL, Wang Z, Zhang $\mathrm{Z}$, Zheng R, Yang L, Zeng L. Multigeneration analysis reveals the inheritance, specificity, and patterns of CRISPR/Cas-induced gene modifications in Arabidopsis. Proc Natl Acad Sci USA. 2014;111(12):4632-7.

89. Liu R, Chen L, Jiang Y, Zhou Z, Zou G. Efficient genome editing in filamentous fungus Trichoderma reesei using the CRISPR/ Cas9 system. Cell Discov. 2015;1(1):1-1.

90. Liu Q, Gao R, Li J, Lin L, Zhao J, Sun W, Tian C. Development of a genome-editing CRISPR/Cas9 system in thermophilic fungal Myceliophthora species and its application to hypercellulase production strain engineering. Biotechnol Biofuels. 2017;10(1):1-4.

91. Yang P, Wu Y, Zheng Z, Cao L, Zhu X, Mu D, Jiang S. CRISPRCas9 approach constructing cellulase sestc-engineered Saccharomyces cerevisiae for the production of orange peel ethanol. Front Microbiol. 2018;9:2436.

92. Abdulrachman D, Eurwilaichitr L, Champreda V, Chantasingh D, Pootanakit K. Development of a CRISPR/Cpf1 system for targeted gene disruption in Aspergillus aculeatus TBRC 277. BMC Biotechnol. 2021;21(1):1-13.

93. Alok A, Sandhya D, Jogam P, Rodrigues V, Bhati KK, Sharma $\mathrm{H}$, Kumar J. The rise of the CRISPR/Cpf1 system for efficient genome editing in plants. Front Plant Sci. 2020;11:264.

94. Ouedraogo JP, Tsang A. CRISPR-Cas systems for fungal research. Fungal Biol Rev. 2020;34(4):189-201.

95. Adiego-Pérez B, Randazzo P, Daran JM, Verwaal R, Roubos JA, Daran-Lapujade P, Van Der Oost J. Multiplex genome editing of microorganisms using CRISPR-Cas. FEMS Microbiol Lett. 2019;366(8):fnz086

96. Singh A, Patel AK, Adsul M, Mathur A, Singhania RR. Genetic modification: a tool for enhancing cellulase secretion. Biofuel Res J. 2017;4(2):600-10.

97. Guazzaroni ME, Platero RA, Silva-Rocha R. Genomic and postgenomic approaches to understand environmental microorganisms. Int J Genomics. 2018. https://doi.org/10.1155/2018/49153 48.

98. Xue Y, Han J, Li Y, Liu J, Gan L, Long M. Promoting cellulase and hemicellulase production from Trichoderma orientalis EU722 by overexpression of transcription factors Xyr1 and Ace3. Bioresour Technol. 2020;296: 122355.

99. Wang L, Lv X, Cao Y, Zheng F, Meng X, Shen Y, Chen G, Liu W, Zhang W. A novel transcriptional regulator RXE1 modulates the essential transactivator XYR1 and cellulase gene expression in Trichoderma reesei. Appl Microbiol Biotechnol. 2019;103(11):4511-23.

100. Cao Y, Zheng F, Wang L, Zhao G, Chen G, Zhang W, Liu W. Rce1, a novel transcriptional repressor, regulates cellulase gene expression by antagonizing the transactivator Xyrl in Trichoderma reesei. Mol Microbiol. 2017;105(1):65-83.

101. Liu P, Lin A, Zhang G, Zhang J, Chen Y, Shen T, Zhao J, Wei D, Wang W. Enhancement of cellulase production in Trichoderma reesei RUT-C30 by comparative genomic screening. Microb Cell Fact. 2019;18(1):81.

102. Mhuantong W, Charoensri S, Poonsrisawat A, Pootakham W, Tangphatsornruang S, Siamphan C, Suwannarangsee S, Eurwilaichitr L, Champreda V, Charoensawan V, Chantasingh D. High quality Aspergillus aculeatus genomes and transcriptomes: 
a platform for cellulase activity optimization toward industrial applications. Front Bioeng Biotechnol. 2021;8: 607176.

103. Luo Y, Valkonen M, Jackson RE, Palmer JM, Bhalla A, Nikolaev I, Saloheimo M, Ward M. Modification of transcriptional factor ACE3 enhances protein production in Trichoderma reesei in the absence of cellulase gene inducer. Biotechnol Biofuels. 2020;13(1):1-16.

104. Han L, Liu K, Ma W, Jiang Y, Hou S, Tan Y, Yuan Q, Niu K, Fang X. Redesigning transcription factor Cre1 for alleviating carbon catabolite repression in Trichoderma reesei. Synth Syst Biotechnol. 2020;5(3):230-5.

105. Martins-Santana L, Paula RGD, Silva AG, Lopes DCB, Silva RDN, Silva-Rocha R. CRZ1 regulator and calcium cooperatively modulate holocellulases gene expression in Trichoderma reesei QM6a. Genet Mol Biol. 2020;43(2):e20190244.

106. Meng QS, Zhang F, Liu CG, Zhao XQ, Bai FW. Identification of a novel repressor encoded by the putative gene $c t f 1$ for cellulase biosynthesis in Trihoderma reesei through artificial zinc finger engineering. Biotechnol Bioeng. 2020;117(6):1747-60.

107. Samal A, Craig JP, Coradetti ST, Benz JP, Eddy JA, Price ND, Glass NL. Network reconstruction and systems analysis of plant cell wall deconstruction by Neurospora crassa. Biotechnol Biofuels. 2017;10(1):1-21.

108. Huberman LB, Coradetti ST, Glass NL. Network of nutrientsensing pathways and a conserved kinase cascade integrate osmolarity and carbon sensing in Neurospora crassa. Proc Natl Acad Sci USA. 2017;114(41):E8665-74.

109. Kim JE, Nam H, Park J, Choi GJ, Lee YW, Son H. Characterization of the CCAAT-binding transcription factor complex in the plant pathogenic fungus Fusarium graminearum. Sci Rep. 2020;10(1):1-11.

110. Bayram ÖS, Dettmann A, Karahoda B, Moloney NM, Ormsby T, McGowan J, Cea-Sánchez S, Miralles-Durán A, Brancini GT, Luque EM, Fitzpatrick DA. Control of development, secondary metabolism and light-dependent carotenoid biosynthesis by the velvet complex of Neurospora crassa. Genetics. 2019;212(3):691-710.

111. Zhao S, Liao XZ, Wang JX, Ning YN, Li CX, Liao LS, Liu Q, Jiang Q, Gu LS, Fu LH, Yan YS. Transcription factor Atf1 regulates expression of cellulase and xylanase genes during solid-state fermentation of ascomycetes. Appl Env Microbiol. 2019;85(24): e01226-19.

112. Yao G, Li Z, Wu R, Qin Y, Liu G, Qu Y. Penicillium oxalicum PoFlbC regulates fungal asexual development and is important for cellulase gene expression. Fungal Genet Biol. 2016;86:91-102.

113. Zhao S, Liu Q, Wang JX, Liao XZ, Guo H, Li CX, Zhang FF, Liao LS, Luo XM, Feng JX. Differential transcriptomic profiling of filamentous fungus during solid-state and submerged fermentation and identification of an essential regulatory gene PoxMBF1 that directly regulated cellulase and xylanase gene expression. Biotechnol Biofuels. 2019;12(1):1-4.

114. Schmoll M. Regulation of plant cell wall degradation by light in Trichoderma. Fungal Biol Biotechnol. 2018;5(1):1-20.

115. Antonieto AC, Nogueira KM, de Paula RG, Nora LC, Cassiano MH, Guazzaroni ME, Almeida F, da Silva TA, Ries LN, de Assis LJ, Goldman GH. A novel Cys2His2 zinc finger homolog of AZF1 modulates holocellulase expression in Trichoderma reesei. mSystems. 2019;4(4): e00161-19.

116. Li Y, Hu Y, Zhu Z, Zhao K, Liu G, Wang L, Qu Y, Zhao J, Qin Y. Normal transcription of cellulolytic enzyme genes relies on the balance between the methylation of H3K36 and H3K4 in Penicillium oxalicum. Biotechnol Biofuels. 2019;12(1):1-19.

117. Zheng F, Cao Y, Wang L, Lv X, Meng X, Zhang W, Chen G, Liu W. The mating type locus protein MAT1-2-1 of Trichoderma reesei interacts with Xyr1 and regulates cellulase gene expression in response to light. Sci Rep. 2017;7(1):1-3.

118. Wang Y, Liu R, Liu H, Li X, Shen L, Zhang W, Song X, Liu W, Liu X, Zhong Y (2021) Development of a powerful synthetic hybrid promoter to improve the cellulase system of Trichoderma Reesei for efficient saccharification of corncob residues. 09 June 2021, PREPRINT (Version 1) available at Research Square https://doi.org/10.21203/rs.3.rs-584234/v1

119. Sun X, Xue X, Li M, Gao F, Hao Z, Huang H, Luo H, Qin L, Yao B, Su X. Efficient coproduction of mannanase and cellulase by the transformation of a codon-optimized endomannanase gene from Aspergillus niger into Trichoderma reesei. J Agric Food Chem. 2017;65(50):11046-53.

120. Miao T, Basit A, Wen J, Liu J, Zheng F, Cao Y, Jiang W. High efficient degradation of glucan/glucomannan to cello-/mannanoligosaccharide by endoglucanase via tetrasaccharide as intermediate. Food Chem. 2021;350: 129175.

121. Akbarzadeh A, Pourzardosht N, Dehnavi E, Siadat SOR, Zamani MR, Motallebi M, Jamnani FN, Aghaeepoor M, Tashnizi MB. Disulfide bonds elimination of endoglucanase II from Trichoderma reesei by site-directed mutagenesis to improve enzyme activity and thermal stability: an experimental and theoretical approach. Int J Biol Macromol. 2018;120:1572-80.

122. Tang H, Song M, He Y, Wang J, Wang S, Shen Y, Hou J, Bao X. Engineering vesicle trafficking improves the extracellular activity and surface display efficiency of cellulases in Saccharomyces cerevisiae. Biotechnol Biofuels. 2017;10(1):1-13.

123. Manglekar RR, Geng A. CRISPR-Cas9-mediated seb1 disruption in Talaromyces pinophilus EMU for its enhanced cellulase production. Enzyme Microb Technol. 2020;140: 109646.

124. Adewumi IK, Ogedengbe MO, Adepetu JA, Aina PO. Aerobic composting of municipal solid wastes and poultry manure. J Appl Sci Res. 2005;1:292-7.

125. Boase NA, Kelly JM. A role for $c r e D$, a carbon catabolite repression gene from Aspergillus nidulans, in ubiquitination. Mol Microbiol. 2004;53(3):929-40.

126. Brown B, Aaron M. The politics of nature. In: Smith J, editor. The rise of modern genomics. 3rd ed. New York: Wiley; 2001. p. 230-57.

127. Carroll A, Somerville C. Cellulosic biofuels. Annu Rev Plant Biol. 2009;60:165-82.

128. Das A, Paul T, Jana A, Halder SK, Ghosh K, Maity C, Das Mohapatra PK, Pati BR, Mondal KC. Bioconversion of rice straw to sugar using multizyme complex of fungal origin and subsequent production of bioethanol by mixed fermentation of Saccharomyces cerevisiae MTCC 173 and Zymomonas mobilis MTCC 2428. Ind Crops Prod. 2013;46:217-25.

129. de Vries RP, Visser JA. Aspergillus enzymes involved in degradation of plant cell wall polysaccharides. Microbiol Mol Biol Rev. 2001;65(4):497-522.

130. Häkkinen M, Valkonen MJ, Westerholm-Parvinen A, Aro N, Arvas M, Vitikainen M, Penttilä M, Saloheimo M, Pakula TM. Screening of candidate regulators for cellulase and hemicellulase production in Trichoderma reesei and identification of a factor essential for cellulase production. Biotechnol Biofuels. 2014;7(1):1-21.

131. Jäger G, Girfoglio M, Dollo F, Rinaldi R, Bongard H, Commandeur U, Fischer R, Spiess AC, Büchs J. How recombinant swollenin from Kluyveromyces lactis affects cellulosic substrates and accelerates their hydrolysis. Biotechnol Biofuels. 2011;4(1):1-6.

132. Le Rhun A, Escalera-Maurer A, Bratovič M, Charpentier E. CRISPR-Cas in Streptococcus pyogenes. RNA Biol. 2019;16(4):380-9.

133. Li J, Zhang Y, Li J, Sun T, Tian C. Metabolic engineering of the cellulolytic thermophilic fungus Myceliophthora thermophila 
to produce ethanol from cellobiose. Biotechnol Biofuels. 2020;13(1):23.

134. Li YL, Li H, Li AN, Li DC. Cloning of a gene encoding thermostable cellobiohydrolase from the thermophilic fungus Chaetomium thermophilum and its expression in Pichia pastoris. J Appl Microbiol. 2009;106(6):1867-75.

135. Manoli MT, Espeso EA. Modulation of calcineurin activity in Aspergillus nidulans: the roles of high magnesium concentrations and of transcriptional factor CrzA. Mol Microbiol. 2019;111(5):1283-301.

136. Moon SB, Lee JM, Kang JG, Lee NE, Ha DI, Kim SH, Yoo K, Kim D, Ko JH, Kim YS. Highly efficient genome editing by CRISPR-Cpf1 using CRISPR RNA with a uridinylate-rich 3'-overhang. Nat Commun. 2018;9(1):1-11.

137. Nitta M, Furukawa T, Shida Y, Mori K, Kuhara S, Morikawa Y, Ogasawara W. A new Zn (II) 2Cys6-type transcription factor BglR regulates $\beta$-glucosidase expression in Trichoderma reesei. Fungal Genet Biol. 2012;49(5):388-97.

138. Panchapakesan A, Shankar N. Fungal cellulases: an overview. In: Gupta V, editor. New and future developments in microbial biotechnology and bioengineering. Elsevier; 2016. p. 9-18.

139. Prabhu RR, Parashar D, Satyanarayana T. Production and characteristics of the recombinant extracellular bifunctional endoglucanase of the polyextremophilic bacterium Bacillus halodurans and its applicability in saccharifying agro-residues. Bioprocess Biosyst Eng. 2017;40(5):651-62.

140. Rahman Z, Shida Y, Furukawa T, Suzuki Y, Okada H, Ogasawara W, Morikawa Y. Application of Trichoderma reesei cellulase and xylanase promoters through homologous recombination for enhanced production of extracellular $\beta$-glucosidase I. Biosci Biotechnol Biochem. 2009;73(5):1083-9.

141. Sun FF, Bai R, Yang H, Wang F, He J, Wang C, Tu M. Heterologous expression of codon optimized Trichoderma reesei Cel6A in Pichia pastoris. Enzyme Microb Technol. 2016;92:107-16.

142. Thakur MK, Thakur VK, Gupta RK, Pappu A. Synthesis and applications of biodegradable soy based graft copolymers: a review. ACS Sustain Chem Eng. 2016;4(1):1-7.

143. Todd RB, Zhou M, Ohm RA, Leeggangers HA, Visser L, De Vries RP. Prevalence of transcription factors in ascomycete and basidiomycete fungi. BMC Genomics. 2014;15(1):1-2.
144. Vázquez-Montoya EL, Castro-Ochoa LD, Maldonado-Mendoza IE, Luna-Suárez S, Castro-Martínez C. Moringa straw as cellulase production inducer and cellulolytic fungi source. Rev Argent Microbiol. 2020;52(1):4-12.

145. Wei Y, Zhou H, Zhang J, Zhang L, Geng A, Liu F, Zhao G, Wang S, Zhou Z, Yan X. Insight into dominant cellulolytic bacteria from two biogas digesters and their glycoside hydrolase genes. PLoS ONE. 2015;10(6): e0129921.

146. Xiao H, Bao Z, Zhao H. High throughput screening and selection methods for directed enzyme evolution. Ind Eng Chem Res. 2015;54(16):4011-20.

147. Srivastava N, Elgorban AM, Mishra PK, Marraiki N, Alharbi AM,Ahmad I, Gupta VK. Enhance production of fungal cellulase cocktail using cellulosic waste. Environ Technol Inno.2020; 19:100949.

148. Singhania RR, Sukumaran RK, Patel AK, Larroche C, Pandey A. Advancement and comparative profiles in the production technologies using solid-state and submerged fermentation for microbialcellulases. Enzyme Microb Technol. 2010;46(7):541-9.

149. Zou G, Shi S, Jiang Y, van den BrinkJ, de Vries RP, Chen L, Zhang J, Ma L, Wang C, Zhou Z. Construction of a cellulase hyper-expression system inTrichoderma reesei by promoter and enzyme engineering. Microb Cell Fact. 2012;11(1):1-2.

150. Bower BS, Larenas EA, Mitchinson C.Exo-endo cellulase fusion protein. WO Patent WO2005093073. 2005.

151. Liu D, Zhang R, Yang X, Zhang Z,Song S, Miao Y, Shen Q. Characterization of a thermostable $\beta$-glucosidase from Aspergillus fumigatus Z5, and itsfunctional expression in Pichia pastoris X33. Microb Cell Fact. 2012;11(1):1-5.

152. Packer MS, Liu DR. Methods for the directed evolution ofproteins. Nat Rev Gen. 2015;16(7):379-94

153. Payne CM, Resch MG, Chen L, Crowley MF, Himmel ME, Taylor LE,Sandgren M, Ståhlberg J, Stals I, Tan Z, Beckham GT. Glycosylated linkers in multimodular lignocellulosedegradingenzymes dynamically bind to cellulose. PNAS. 2013;110(36):14646-51.

154. Wei W, Chen L, Zou G,Wang Q, Yan X, Zhang J, Wang C, Zhou Z. N-glycosylation affects the proper folding, enzymatic characteristicsand production of a fungal $\beta$-glucosidase. Biotechnol Bioeng. 2013;110(12):3075-84. 